\title{
A Dangerous Distinction: The Deconstitutionalization of Private SPEECH
}

\author{
Derigan Silver $^{\dagger}$ \& Ruth Walden ${ }^{\dagger}$
}

\section{INTRODUCTION}

In 1948, Professor Alexander Meiklejohn proposed that the First Amendment to the United States Constitution be interpreted as absolutely protecting speech that contributed to self-government,' or public speech. For Meiklejohn, the purpose of the First Amendment's guarantee of freedom of speech and the press was to ensure that all speech relevant to democratic debate be heard, thereby enabling citizens to engage in effective self-government. ${ }^{2}$ Thus, Meiklejohn argued that the Amendment protected only speech that contributed to self-government. ${ }^{3}$

In the mid-1960s the U.S. Supreme Court began applying a decidedly Meiklejohnian approach to certain First Amendment claims, using a selfgovernment rationale to justify enhanced protection for freedom of expression on matters of public concern or public interest. The process began with the Court's 1964 New York Times v. Sullivan decision, in which the Court estab-

\$ Assistant Professor, Department of Media, Film and Journalism Studies, Adjunct Faculty, Sturm College of Law, University of Denver; Ph.D., Mass Communication, University of North Carolina at Chapel Hill. M.A., Journalism, Arizona State University. B.A., Psychology, University of California at Santa Barbara.

$\dagger$ Professor Emerita, School of Journalism \& Mass Communication, University of North Carolina at Chapel Hill; Ph.D., M.A. \& B.A., University of Wisconsin-Madison. A previous version of this article was presented at the 2012 Southeast Colloquium of the Association for Education in Journalism and Mass Communication.

1 See generally Alexander Meiklejohn, Free Speech and Its Relation to SelfGovernment 3, 17-19 (1948) [hereinafter Meiklejohn, Free Speech].

2 See id. at 22-27 (using an American town meeting to illustrate what the First Amendment's protections attempt to guarantee).

3 Professor Meiklejohn wrote that private speech was unprotected by the First Amendment but was covered by the Due Process Clause of the Fifth Amendment. Id. at 37-39. See also infra notes 76-119 and accompanying text for a discussion of Meiklejohn's approach and subsequent authors who have espoused the public or political speech principle. 
lished the actual malice fault requirement for public officials suing for libel, recognizing "a profound national commitment to the principle that debate on public issues should be uninhibited, robust, and wide-open . . . ." Three years later, the Court extended the actual malice requirement to "false light" invasion of privacy lawsuits based on "false reports of matters of public interest," and the following year the justices ruled that public employees may not be penalized for speaking out on "issues of public importance." ${ }^{6}$ More recently, in Snyder $v$. Phelps, a highly publicized case involving protests at military funerals by the Westboro Baptist Church, the Court wrote that the distinction between public and private speech was critical to the outcome of the case. ${ }^{7}$

As the Supreme Court used Alexander Meiklejohn's public speech rationale to support expansion of First Amendment free speech rights in the 1960s and 1970s, it refrained from ever acknowledging the remainder of Meiklejohn's argument-that private speech is outside the purview of the First Amendment. ${ }^{8}$ Not until the mid-1980s did the Court directly confront the question of whether speech on non-public issues warranted First Amendment protection, but its pronouncements on the issue were less than clear: "In contrast, speech on matters of purely private concern is of less First Amendment concern. . . . While such speech is not totally unprotected by the First Amendment, its protections are less stringent."

Despite the Court's cautious language, some lower courts have chosen to drop the "not" from the quote above, interpreting speech about private people and matters of private concern to be totally without First Amendment protection. ${ }^{10}$ One of the best known of these cases occurred in 2009 when the U.S.

4 N.Y. Times Co. v. Sullivan, 376 U.S. 254, 270 (1964) (emphasis added); see also Garrison v. Louisiana, 379 U.S. 64, 67 (1964) (holding the actual malice requirement also applies in criminal libel prosecutions based on defamatory statements about public officials); Curtis Publ'g Co. v. Butts, 388 U.S. 130, 163-65 (1967) (Warren, C.J., concurring) (disagreeing with the majority's "highly unreasonable conduct" standard for "public figures" and instead applying the actual malice standard).

5 Time, Inc. v. Hill, 385 U.S. 374, 388-90 (1967) (emphasis added).

6 Pickering v. Bd. of Educ., 391 U.S. 563, 574 (1968) (emphasis added).

7 Snyder v. Phelps, 131 S. Ct. 1207, 1215 (2011).

8 MEIKLEJOHN, FREE SPEECH, supra note 1, at 37-39 (contending that private speech was unprotected by the First Amendment but covered only by the Due Process Clause of the Fifth Amendment).

9 Dun \& Bradstreet, Inc. v. Greenmoss Builders, Inc., 472 U.S. 749, 759-60 (1985) (citation omitted).

10 See, e.g., Snead v. Redland Aggregates Ltd., 998 F.2d 1325, 1334 (5th Cir. 1993) ("We therefore conclude that the Constitution imposes no minimum standard of fault in private/private libel cases."); Sleem v. Yale Univ., 843 F. Supp. 57, 62 (M.D.N.C. 1993) ("Dun \& Bradstreet allows the states to choose whether to allow presumed damages and impose liability without fault in cases involving private person plaintiffs and non-public issues.”); Weissman v. Sri Lanka Curry House, 469 N.W.2d 471, 473 (Minn. Ct. App. 1991) ("Because the Supreme Court has not extended constitutional protections for public speech 
Court of Appeals for the First Circuit refused to hold unconstitutional a Massachusetts law that allowed liability for true defamatory statements. "Stating that the defendant did "not cite a case for the proposition that the First Amendment does not permit liability for true statements concerning matters of private concern," 12 the First Circuit permitted common law actual malice, which it defined as "actual malevolent intent or ill will" to overcome a truth defense. ${ }^{13}$ In other words, so long as a speaker was motivated by ill will, he or she could be held liable for damages for a completely true statement if the statement was about a private person and a matter of private concern.

In 2010, the Florida Supreme Court also recognized that truthful statements made with bad motives could result in libel damages when it approved new standard jury instructions for civil cases in the state. ${ }^{14}$ In the section addressing defamation actions brought by private plaintiffs against nonmedia defendants, the jury instructions recognize the defense "of truth and good motives."15 Similarly, some courts have ruled that nonmedia defendants enjoy different constitutional rights than media defendants. For example, in late 2011, the U.S. District Court for the District of Oregon held that a blogger was not entitled to constitutional protections because she was not a member of the media. ${ }^{16}$

Potential liability for truthful statements and different constitutional standards for media and nonmedia are not the only byproducts of the Supreme Court's ambiguity on the availability of First Amendment protection for defamatory statements about private persons and matters of private concern. Lower courts have ruled, or at least suggested, that in private-person-privateissue cases there may neither be a constitutional fault requirement ${ }^{17}$ nor a constitutional protection for statements of opinion. ${ }^{18}$

to speech of purely private concern, . . . private plaintiff/private issue defamation actions must be analyzed under state common law principles.").

11 Noonan v. Staples, Inc., 561 F.3d 4, 6-7 (1st Cir. 2009).

12 Id. at 6-7.

13 Noonan v. Staples, Inc., 556 F.3d 20, 28-29(1st Cir. 2009), reh'g and reh'g en banc denied, $561 \mathrm{~F} .3 \mathrm{~d} 4$ (1st Cir. 2009). In October 2009 a jury failed to find common law actual malice and ruled in favor of the defendant. Tresa Baldas, Jury Says No to Libel Claim Over Truthful E-Mail, LAw.COM (Oct. 13, 2009), http://commens.org/VYfTWn.

14 See In re Standard Jury Instructions in Civil Cases-Report No. 09-01, 35 So. 3d 666, 733-34 (Fla. 2010).

15 Id. at 730.

16 Obsidian Fin. Grp., LLC v. Cox, No. CV-11-57-HZ, 2011 WL 5999334, at *1 (D. Or. Nov. 30, 2011).

17 See Snead v. Redland Aggregates Ltd., 998 F.2d 1325, 1334 (5th Cir. 1993) ("We therefore conclude that the Constitution imposes no minimum standard of fault in private/private libel cases."); see also Sleem v. Yale Univ., 843 F. Supp. 57, 62 (M.D.N.C. 1993) ("Dun \& Bradstreet allows the states to choose whether to allow presumed damages and impose liability without fault in cases involving private person plaintiffs and non-public issues.").

18 See Roffman v. Trump, 754 F. Supp. 411, 415-16 (E.D. Pa. 1990) (ruling that Milk- 
While the "deconstitutionalization" of private speech has been most apparent in defamation cases, the trickledown effect of adopting a Meiklejohnian approach is certainly not limited to defamation. ${ }^{19}$ The Supreme Court never explicitly stated that private speech is unprotected by the First Amendment, but it has emphasized the constitutional importance of public speech in cases involving speech by government employees, ${ }^{20}$ intentional infliction of emotional distress, ${ }^{21}$ and false light invasion of privacy, ${ }^{22}$ as well as others. ${ }^{23}$ While this article focuses on defamation law, the implications of the Court's embrace of a Meiklejohnian approach reaches across numerous categories of communications law. In effect, lower courts are removing a wide range of speech from constitutional protections at the very time that new communication technologies such as email, Facebook, Twitter, and blogs are giving private individuals the power to reach wider and wider audiences. Thus, although it may be true that through the Internet "any person . . . can become a town crier with a voice that resonates farther than it could from any soapbox," ${ }^{24}$ if a court decides the town crier's speech does not involve a matter of public concern it might have no constitutional protection.

The purpose of this article is to identify the extent to which lower federal courts and state courts have, in effect, deconstitutionalized private defamatory speech. Part II provides an overview of the development of constitutional pro-

ovich v. Lorain Journal Co., 497 U.S. 1 (1990), was inapplicable in a private-private libel action and that state law was determinative); Weissman v. Sri Lanka Curry House, 469 N.W.2d 471, 473 (Minn. Ct. App. 1991) ("Because the Supreme Court has not extended constitutional protections for public speech to speech of purely private concern, ... private plaintiff/private issue defamation actions must be analyzed under state common law principles.").

19 See Connick v. Myers, 461 U.S. 138, 154 (1983) (employment civil rights claim); Pickering v. Bd. of Educ., 391 U.S. 563, 574 (1968); see e.g., Bartnicki v. Vopper, 532 U.S. 514, 535 (2001) (unlawful wiretaps); Time, Inc. v. Hill, 385 U.S. 374, 387-88 (1967) (state right of privacy); Snyder v. Phelps, $131 \mathrm{~S}$. Ct. 1207, 1215 (2011) (intentional infliction of emotional distress). "Deconstitutionalization" is a term of art that has been used by legal scholars to describe the refusal to enforce constitutional protections in school settings, the public sector work space, and other areas of law. See, e.g., Erwin Chemerinsky, The Deconstituionalization of Education, 36 LoY. U. CHI.. L.J. 111 (2004).

20 See Connick, 461 U.S. at 154 (recognizing the "practical realities" in regards to the actions of employees in government offices); Pickering, 391 U.S. at 573 (denying recovery for defamatory statements unless made with knowledge of falsity).

21 See, e.g., Snyder, 131 S. Ct. at 1215 ("The Free Speech Clause of the First Amendment . . . can serve as a defense in state tort suits, including suits for intentional infliction of emotional distress.").

22 See, e.g., Hill, 385 U.S. at 387-88 (First Amendment protections require a showing that defendant acted with knowledge of report's falsehood or acted with reckless disregard of the truth).

23 See, e.g., Bartnicki, 532 U.S. at 535 (illegally recorded conversation regarding matter of public concern released by media protected by First Amendment).

24 Reno v. ACLU, 521 U.S. 844, 870 (1997). 
tection for defamatory speech and the subsequent erosion of protection for private libel. Part III briefly reviews literature related to the public speech/private speech dichotomy. Part IV surveys and analyzes cases in which courts expressly adopted the view that the First Amendment does not protect private speech, as well as cases in which courts took the lesser, more tentative step of merely questioning whether constitutional protections apply to private speech. Each section of the case analysis focuses on a separate element of defamation law affected by constitutional considerations. Section A addresses the falsity/truth element, Section B fault, Section C the First Amendment opinion defense, and Section $D$ the question of whether constitutional protections apply to nonmedia defamation defendants. Part IV discusses why the Meiklejohnian approach is disconcerting, and argues the Supreme Court should stop confusing lower courts with dangerous dicta, ${ }^{25}$ which is leading to the deconstitutionalization of private speech.

\section{LIBEL LAW AND THE FIRST AMENDMENT: THE CONSTITUTIONALIZATION OF THE LAW OF LIBEL}

As noted above, the Supreme Court began the process of applying constitutional protections to the law of libel in the 1964 decision New York Times Co. v. Sullivan, holding that the First Amendment requires a public official claiming libel to prove with convincing clarity that the defamatory statement was published with knowledge of its falsity or reckless disregard for the truth. ${ }^{26}$ The Court labeled this fault standard "actual malice."27 A few months later, the Court again applied the actual malice fault requirement, extending it to criminal libel actions brought as the result of criticism of public officials. ${ }^{28}$ As it had in New York Times, the Court relied on the Meiklejohnian theory without directly citing or quoting Alexander Meiklejohn: "For speech concerning public affairs is more than self-expression; it is the essence of self-government."29

During the following decade, the Court grappled with just how far the actual malice requirement should reach. In 1967, the Court decided that in false light invasion of privacy actions arising from "reports of matters of public interest,"

25 As noted below and as discussed by other scholars, much of the Court's discussion of political speech theories has occurred in dicta. See, e.g., C. Edwin Baker, Is Democracy a Sound Basis for a Free Speech Principle?, 97 VA. L. REV. 515, 528 (2011) ("The Court's comments, usually in dicta, that refer to political speech being the at the core of the First Amendment can be counterpoised to possibly the most widely invoked black letter rule-the presumptive unconstitutionality of content discrimination.").

26 N.Y. Times Co. v. Sullivan, 376 U.S. 254, 279-80 (1964).

27 Id. at 284-85.

28 Garrison v. Louisiana, 379 U.S. 64, 80-81 (1964).

29 Id. at 74-75. 
plaintiffs would have to prove actual malice to prevail..$^{30} \mathrm{~A}$ few months later in the companion cases Curtis Publishing Co. v. Butts and Associated Press v. Walker, a four-member plurality of the Court held that public figures would need to show "highly unreasonable conduct constituting an extreme departure from the standards of investigation and reporting ordinarily adhered to by responsible publishers" to win libel actions. ${ }^{31}$ In a concurring opinion, Chief Justice Earl Warren called for application of the same fault standard-knowledge of falsity or reckless disregard for the truth-to both public figures and public officials. He reasoned that both categories of individuals "often play an influential role in ordering society" and have "ready access" to the mass media "both to influence policy and to counter criticism of their views and activities." 32 Furthermore, Chief Justice Warren argued that citizens have "a legitimate and substantial interest in the conduct" of public figures, and "freedom of the press to engage in uninhibited debate about their involvement in public issues and events is as crucial as it is in the case of "public officials."'"33

In the 1971 case of Rosenbloom v. Metromedia, Inc. ${ }^{34}$ a plurality of the Court, led by Justice William Brennan, decided that the "matters of public interest" standard used four years earlier in the false light case was also the appropriate standard to use to determine when actual malice would be required in defamation cases. ${ }^{35}$ Quoting Justice John Marshall Harlan's opinion in Curtis Publishing Co. $v$ Butts, Justice Brennan reasoned that the framers' intent was that the First Amendment would protect all information of interest to the public, not just statements about public officials and public figures. ${ }^{36}$

Only two other justices concurred in Justice Brennan's Rosenbloom opinion, ${ }^{37}$ and just three years later the Court shifted its position by finding that a plaintiff's status should determine the fault standard to be applied in defamations cases. In Gertz v. Robert Welch, Inc., the Court ruled that, while public officials and public figures must prove actual malice to prevail in libel suits, private individuals must prove negligence, though states were free to establish a higher standard of fault for private persons if they chose. ${ }^{38}$ This lower fault standard for private individuals, however, applied only to the awarding of ac-

\footnotetext{
Time, Inc. v. Hill, 385 U.S. 374, 387-88 (1967).

Curtis Publ'g Co. v. Butts, 388 U.S. 130, 155 (1967).

Id. at 164 (Warren, C.J., concurring).

Id. at 164 (Warren, C.J., concurring).

See Rosenbloom v. Metromedia, Inc., 403 U.S. 29 (1971).

See id. at 51-52.

Id. at 42 ("'[T]he Founders . . . felt that a free press would advance 'truth, science, morality, and arts in general' as well as responsible government." (quoting Curtis Publ'g Co. v. Butts, 388 U.S. 130, 147 (1967) (Harlan, J., concurring))).

37 Namely, Chief Justice Earl Warren and Justice Harry Blackmun. Rosenbloom, 403

38 Gertz v. Robert Welch, Inc., 418 U.S. 323, 344-48 (1974).
} U.S. at 30 . 
tual damages. ${ }^{39}$ All plaintiffs, public and private, would have to prove actual malice to recover presumed or punitive damages. ${ }^{40}$ Justice Lewis Powell, writing for the majority, observed that "the doctrine of presumed damages invites juries to punish unpopular opinion rather than to compensate individuals for injury sustained by the publication of a false fact," damages as "private fines levied by civil juries to punish reprehensible conduct and to deter its future occurrence." 42

It's important to emphasize that the Gertz majority never stated that its decision was contingent upon the subject of the allegedly defamatory statement being a matter of public concern. Indeed the majority opinion rejected the idea that constitutional protection should hinge on subject matter. Justice Powell wrote that such an approach "would occasion the additional difficulty of forcing state and federal judges to decide on an ad hoc basis which publications address issues of 'general or public interest' and which do not .... We doubt the wisdom of committing this task to the conscience of judges." ${ }^{, 43}$

While clarifying the rules as to which level of fault plaintiffs would have to prove to win their libel cases, the majority opinion in Gertz also introduced uncertainty as to whether the defendant's status impacted which level of fault was required. At the outset, Justice Powell defined the issue in Gertz as "whether a newspaper or broadcaster that publishes defamatory falsehoods about an individual who is neither a public official nor a public figure may claim a constitutional privilege against liability for the injury inflicted by those statements. ${ }^{, 44}$ Throughout the opinion, Justice Powell repeatedly referred to the need to protect "publishers," "broadcasters" and "the media" from juries ${ }^{45}$ words that led some courts to conclude that constitutional limits did not apply in cases involving nonmedia defendants. ${ }^{46}$

39 Id. at 349.

40 Id.

41 Id.

42 Id. at 350 .

43 Id. at 346

44 Id. at 332 (emphasis added).

45 See id. at 340 ("Our decisions recognize that a rule of strict liability that compels a publisher or broadcaster to guarantee the accuracy of his factual assertions may lead to intolerable self-censorship. Allowing the media to avoid liability only by proving the truth of all injurious statements does not accord adequate protection to First Amendment liberties.") (emphasis added); id. at 341 ("The need to avoid self-censorship by the news media is, however, not the only societal value at issue. If it were, this Court would have embraced long ago the view that publishers and broadcasters enjoy an unconditional and indefeasible immunity from liability for defamation.") (emphasis added); id. at 350 (1974) ("Like the doctrine of presumed damages, jury discretion to award punitive damages unnecessarily exacerbates the danger of media self-censorship.") (emphasis added).

46 See Rowe v. Metz, 579 P.2d 83, 84 (Colo. 1978) ("While it is true that our decision today means that media and nonmedia defendants may be treated differently in certain areas 


\section{A. Chipping Away at Protection for Private Defamatory Speech}

It was the Vermont Supreme Court's decision that Gertz did not apply to nonmedia defendants that brought Dun \& Bradstreet, Inc. v. Greenmoss Builders, Inc. ${ }^{47}$ to the U.S. Supreme Court in 1985. A jury had awarded Greenmoss Builders $\$ 50,000$ in compensatory or presumed damages and $\$ 300,000$ in punitive damages in a case that resulted from an erroneous credit report sent to five of the defendant's subscribers stating the construction company had filed for bankruptcy. ${ }^{48}$ Dun \& Bradstreet moved for a new trial on the ground that the trial judge's instructions had allowed the jury to award presumed and punitive damages without proof of actual malice. ${ }^{49}$ Although the trial court indicated doubt that Gertz applied to nonmedia defendants, it granted a new trial. ${ }^{50}$ The Vermont Supreme Court reversed, holding that Gertz's First Amendment requirements applied only to media defendants. ${ }^{51}$

"Recognizing disagreement among the lower courts about when the protections of Gertz apply," the U.S. Supreme Court granted certiorari. ${ }^{52}$ Acknowl-

with respect to proof of damages, we are not persuaded that this differentiation is unwarranted."); Harley-Davidson Motorsports, Inc. v. Markley, 568 P.2d 1359, 1362-63 (Ore. 1977) ("In the instant case there is no public official or figure as plaintiff, there is no issue of public concern, and there is no media defendant. The crucial elements in the above cases which brought the United States Supreme Court into the field of defamation law are missing.") (footnote omitted); Greenmoss Builders, Inc. v. Dun \& Bradstreet, Inc., 461 A.2d 414, 417-18 (Vt. 1983) ("There is a clear distinction between a publication which disseminates news for public consumption and one which provides specialized information to a selective, finite audience. We therefore reject, as have the majority of circuit courts, the assertion that credit agencies such as defendant are the type of media worthy of First Amendment protection as contemplated by New York Times and its progeny."), aff'd on other grounds, Dun \& Bradstreet, Inc. v. Greenmoss Builders, Inc., 472 U.S. 749 (1985); Denny v. Mertz, 318 N.W.2d 141, 153 (Wis. 1982) ("While we recognize that some courts in other jurisdictions have held that the Gertz protections apply to all defamations, regardless of whether published through the media or by private persons, we do not read Gertz as requiring that the protections provided therein apply to non-media defendants nor ... do we consider it good public policy to so decide.") (footnotes omitted).

47 See Dun \& Bradstreet, Inc. v. Greenmoss Builders, Inc., 472 U.S. 749, 753 (1985).

48 Id. at 751-52. The error occurred when a 17-year-old employee of Dun \& Bradstreet inadvertently attributed a bankruptcy petition filed by one of Greenmoss' former employees to the firm. Although it was Dun \& Bradstreet's practice to check the accuracy of its reports with the businesses themselves, it did not verify the information about Greenmoss before it issued the report. $I d$. at 752 .

49 Id. at 752.

so Id.

51 Greenmoss Builders, 461 A.2d at $417-18$ ("There is a clear distinction between a publication which disseminates news for public consumption and one which provides specialized information to a selective, finite audience. We therefore reject, as have the majority of circuit courts, the assertion that credit agencies such as defendant are the type of media worthy of First Amendment protection as contemplated by New York Times and its progeny.").

52 Dun \& Bradstreet, 472 U.S. at 753 (footnote omitted). 
edging lower court confusion in distinguishing between media and nonmedia defendants and citing six state supreme court decisions to illustrate the disagreement, ${ }^{53}$ Justice Powell ignored that issue and instead concluded that the limitation on the recovery of presumed and punitive damages established in Gertz did not apply "when the defamatory statements do not involve matters of public concern." 54 Thus, despite the reservations he once voiced in Gertz about the wisdom of judges determining what is and is not of public interest, ${ }^{55}$ Justice Powell's opinion in Dun \& Bradstreet went on to do just that.

In the plurality opinion, Justice Powell characterized Gertz as an effort to balance the states' interest in allowing individuals to be compensated for injury to their reputations with the First Amendment's interest in protecting speech on matters of public concern, emphasizing that "[n]othing in our [Gertz] opinion, however, indicated that this same balance would be struck regardless of the type of speech involved." 56 Although Justice Powell worked hard to convince readers that Dun \& Bradstreet was faithful to-and the natural extension ofGertz, some of his brethren on the Court were not convinced. In his concurring opinion, Justice Byron White reflected on Justice Powell's decision not to follow Gertz: "I had thought that the decision in Gertz was intended to reach cases that involve any false statements of fact injurious to reputation, whether the statement is made privately or publicly and whether or not it implicates a matter of public importance." ${ }^{\text {57 }}$ In a dissent joined by Justices Thurgood Marshall, Harry Blackmun and John Paul Stevens, Justice Brennan pointed out:

One searches Gertz in vain for a single word to support the proposition that limits on presumed and punitive damages obtained only when speech involved matters of public concern. Gertz could not have been grounded in such a premise. Distrust of placing in the courts the power to decide what speech was of public concern was precisely the rationale Gertz offered for rejecting the Rosenbloom plurality approach. ${ }^{58}$

Justice Powell was careful in his plurality opinion to characterize private speech as having "reduced constitutional value," never stating that private defamatory speech was completely unprotected by the First Amendment. However, Chief Justice Warren Burger's and Justice White's concurrences adopted that approach. The Chief Justice's five-paragraph concurrence seemed

53 Id. at 753 \& n.1 (1985) (citing Antwerp Diamond Exch., Inc. v. Better Bus. Bureau, 637 P.2d 733 (Ariz. 1981); Rowe v. Metz, 579 P.2d 83 (Colo 1978); Jacron Sales Co. v. Sindorf, 350 A.2d 688 (Md. 1976); Stuempges v. Parke, Davis \& Co., 297 N.W.2d 252 (Minn. 1980); Harley-Davidson Motorsports, Inc. v. Markley, 568 P.2d 1359 (Or. 1977); Denny v. Metz, 318 N.W.2d 141 (Wis. 1982)).

54 Id. at 763.

55 Gertz v. Robert Welch, Inc., 418 U.S. 323, 346 (1974).

56 Dun \& Bradstreet, 472 U.S. at 756-57 (footnote omitted).

57 Id. at 772 (White, J., concurring).

58 Id. at 785 n.11 (Brennan, J., dissenting).

59 Id. at 761 (majority opinion). 
to have one purpose only: to convince readers that none of Gertz's constitutional rules applied to speech on private matters. ${ }^{60}$ While the plurality opinion carefully restricted itself to the issue at hand-the availability of presumed and punitive damages-Chief Justice Burger put his own spin on what Justice Powell wrote:

The single question before the Court today is whether Gertz applies to this case. The plurality opinion holds that Gertz does not apply because, unlike the challenged expression in Gertz, the alleged defamatory expression in this case does not relate to a matter of public concern. I agree that Gertz is limited to circumstances in which the alleged defamatory expression concerns a matter of general public importance ... ${ }^{61}$

Likewise, Justice White saw the plurality opinion as going beyond the fault level required for punitive and presumed damages: "[I]t must be that the Gertz requirement of some kind of fault on the part of the defendant is also inapplicable in cases such as this." ${ }^{2}$ Justice White himself would have gone even farther, expressly calling for a return to common law rules whenever a libel plaintiff was neither a public official nor a public figure. ${ }^{63}$

The following year, in Philadelphia Newspapers, Inc. v. Hepps, a fivemember majority of the Court ruled that the subject matter of a defamatory report (i.e., "speech of public concern") would govern when the plaintiff had to prove falsity, giving judges an uncomfortably critical role in the determination of what is and what is not a matter of public concern. ${ }^{64}$ Writing for the majority, Justice Sandra Day O'Connor said New York Times and its progeny reflected "two forces" that had reshaped the common law: The plaintiff's status, namely whether they are a public or private figure and "whether the speech at issue is of public concern." Once again, though, the Court stopped short of declaring private defamatory speech wholly unprotected by the First Amendment, stating:

When the speech is of public concern but the plaintiff is a private figure, as in Gertz, the Constitution still supplants the standards of the common law, but the constitutional requirements are, in at least some of their range, less forbidding than when the plaintiff is a public figure and the speech is of public concern. When the speech is of exclusively private concern and the plaintiff is a private figure, as in Dun \& Bradstreet, the constitutional requirements do not necessarily force any change in at least some of the features of the common-law landscape. ${ }^{66}$

Justice O'Connor cited only "two forces" determining constitutional requirements in libel cases, her opinion served to further fuel confusion over

60 Id. at 763-64 (1985) (Burger, C.J., concurring).

61 Id. at 764 (Burger, C.J., concurring).

62 Id. at 774 (White, J., concurring).

63 Id. at 772 (White, J., concurring).

64 Phila. Newspapers, Inc. v. Hepps, 475 U.S. 767, $768-69$ (1986).

65 Id. at 775.

66 Id 
whether the defendant's status was a third force to be considered. ${ }^{67}$ In discussing issues the Court was not required to address, Justice O'Connor explicitly avoided the issue, stating, "Nor need we consider what standards would apply if the plaintiff sues a nonmedia defendant." 68

Finally in 1990, in Milkovich v. Lorain Journal Co., a seven-member majority hinged the constitutional protection of opinions on the subject matter of the article: "[A] statement of opinion relating to matters of public concern which does not contain a provably false factual connotation will receive full constitutional protection. ${ }^{\prime 69}$ The Milkovich Court kept alive the possibility of a medianonmedia distinction, however, by declaring that provable falsity was required "at least in situations, like the present, where a media defendant is involved." That statement was followed by a footnote stating, "In Hepps the Court reserved judgment on cases involving nonmedia defendants, and accordingly we do the same."

While these cases all stand for the proposition that speech on matters of public concern should receive more protection than private speech, it is important to emphasize that a majority of the Supreme Court has never held that the First Amendment is totally inapplicable in private-person-private-issue libel suits. Instead, the Court has used cautious, and sometimes convoluted, language: "reduced constitutional value,"72 "of less First Amendment concern,"73 "not totally unprotected by the First Amendment," and "not necessarily forc[ing] any change in at least some of the features of the common-law landscape."75 The Court has not declared that the identity or status of the defendant-media or nonmedia - governs the applicability of constitutional protections. In Dun \& Bradstreet the Court had the perfect opportunity to rule on that question yet chose to ignore it. In Hepps and Milkovich the Court specifically stated it was not addressing that issue. The message some scholars and lower courts have taken away, however, is that private defamatory speech is-or should be-

67 Id.

68 Id. at 779 n.4 (citing Hutchinson v. Proxmire, 443 U.S. 111,133 n.16 (1979)). In Hutchinson v. Proxmire, where the defendants were a U.S. Senator and his legislative assistant, the Court, applying Gertz, determined that the plaintiff, a research director at a state mental health facility and an adjunct professor, was not a public figure and, therefore, did not need to prove actual malice. Hutchinson v. Proxmire, 443 U.S. 111, 114-15, 134-36 (1979).

69 Milkovich v. Lorain Journal Co., 497 U.S. 1, 20 (1990) (discussing Phila. Newspapers, Inc. v. Hepps, 475 U.S. 767 (1986)).

70 Id. at $19-20$.

71 Id. at 20 n.6 (citation omitted).

72 Dun \& Bradstreet, Inc. v. Greenmoss Builders, Inc., 472 U.S. 749, 761 (1985).

73 Id. at 759.

74 Id. at 760.

75 Phila. Newspapers, Inc. v. Hepps, 475 U.S. 767, 775 (1986). 
constitutionally unprotected.

\section{THE PUBLIC SPEECH-PRIVATE SPEECH DISTINCTION IN THE LITERATURE}

Professor Alexander Meiklejohn is the most prominent First Amendment theorist to argue that the First Amendment should not protect private speech. Because he saw the First Amendment's guarantee of freedom of speech and the press as directly tied to the need for citizens to have access to all relevant information and ideas so that they could effectively self-govern, ${ }^{76}$ Meiklejohn famously concluded that the First Amendment "established an absolute, unqualified prohibition of the abridgement of the freedom of speech."77 Nevertheless, Meiklejohn extended this protection only to speech related to selfgovernment. ${ }^{78}$ Meiklejohn wrote that the purpose of protecting public speech was to "give to every voting member of the body politic the fullest possible participation in the understanding of those problems with which the citizens of a self-governing society must deal." 79 He reasoned that the First Amendment did not protect an individual's right "to speak;" public power, a governmental responsibility," and protects only the "commu-

76 See generally MEIKLEJOHN, FREE SPEECH, supra note 1, at 1-27.

77 Id. at 17.

78 AleXander Meiklejohn, Political Freedom 55 (1948) [hereinafter MeikLejohn, FREEDOM] ("[The First Amendment] is protecting the common needs of all the members of the body politic ... The public discussion of [those needs], therefore, has a constitutional status which no pursuit of an individual purpose can ever claim."). Meiklejohn argued that "private" speech should be protected by a less rigorous standard under the Fifth Amendment, giving only "impartial consideration" to it. Id.

79 MEIKLEJOHN, FREE SPEECH, supra note 1, at 88; see also Alexander Meiklejohn, The First Amendment Is an Absolute, 1961 SUP. CT. REV. 245, 255-57 (1961) [hereinafter Meiklejohn, Absolute]; see generally MEIKLEJOHN, FREE SPEECH, supra note 1, at 1-27. Meiklejohn contended that the First Amendment, like "all other provisions of the Constitution," was best understood in relation to the overall function of the Constitution as a means to establish self-government. Id. at 15 . According to Meiklejohn, the controlling words of the Constitution are in the Preamble, which declares:

We the People of the United States, in Order to form a more perfect Union, establish Justice, insure domestic Tranquillity, provide for the common defence, promote the general Welfare, and secure the Blessings of Liberty to ourselves and our Posterity, do ordain and establish this Constitution for the United States of America.

U.S. CONST. pmbl; see MEIKLEJOHN, FREE SPEECH, supra note 1, at 15 ("In those words it is agreed, and with every passing moment it is reagreed, that the people of the United States shall be self-governed."). Meiklejohn claimed that all other provisions of the document should find their "legitimate scope and meaning only as they conform to the one basic purpose that the citizens of this nation shall make and shall obey their own laws." Id.

80 Meiklejohn, Absolute, supra note 79, at 255. 
nication[s] by which we 'govern." "81

Meiklejohn's focus on self-government has been echoed in the works of other scholars. In 1971, in a lecture delivered at the Indiana University School of Law, then-Professor Robert H. Bork stated, "Constitutional protections should be accorded only to speech that is explicitly political." 82 According to Bork, because the text of the First Amendment could not be taken literally, ${ }^{83}$ and the framers' intent was unclear, ${ }^{84}$ the Amendment should be construed as protecting only speech that advanced the Constitution's overall interest in representative democracy. ${ }^{85}$ Discussing First Amendment values, Bork argued that individual self-fulfillment ${ }^{86}$ and the safety-valve function ${ }^{87}$ - the values used to justify protecting private speech-were not valid reasons for protecting speech. ${ }^{88}$ Unsurprisingly, in his lecture Bork quoted Meiklejohn approvingly, although he felt Meiklejohn would protect too much speech. ${ }^{89}$

Law professor Lillian BeVier, discussing what she called "the political speech principle," wrote that the First Amendment did not protect and was never meant to protect "nonpolitical speech." Extending protection to nonpo-

81 Id

82 Robert H. Bork, Neutral Principles and Some First Amendment Problems, 47 IND. L.J. 1, 20 (1971).

${ }^{83}$ See $i d$. at 21 (contending that a literal, absolute reading of the First Amendment leads to absurd results).

84 See id. at 22 (noting that the "framers seem to have had no coherent theory of free speech and appear not to have been overly concerned with the subject").

85 See id. at 23.

86 Individual self-fulfillment means free speech that helps to develop the faculties of the individual, brings happiness, and is a good unto itself. Thomas I. Emerson, Toward a General Theory of the First Amendment, 72 YALE L.J. 877, 879-80 (1963); see generally Martin H. Redish, The First Amendment in the Marketplace: Commercial Speech and the Values of Free Expression, 39 GeO. WASH. L. REV. 429 (1971); Martin H. Redish, The Value of Free Speech, 130 U. PA. L. REV. 591 (1982).

87 Free expression acts as a safety-valve, allowing critics to "discuss freely supposed grievances and proposed remedies," rather than seeking change through radical acts. Whitney v. Califomia, 274 U.S. 357, 375 (1927) (Brandeis \& Holmes, JJ., concurring); Bork, supra note 82 , at 25-26 (terming this benefit of free speech the "safety valve"); see generally Emerson, supra note 86, at 879-81.

88 Bork, supra note 82 , at 26.

89 Id. at 26. Bork was critical of Meiklejohn's later writings that argued for First Amendment protection for many different kinds of expression, such as novels, dramas, paintings and poems, because literary works informed a citizen's ability to vote. Compare Bork, supra note 82, at 26-27 (calling for the "principled judge" to refuse the tempting invitation to extend First Amendment protection to speech beyond that which is "explicitly political"), with Meiklejohn, Absolute, supra note 79, at 263 ("I believe, as a teacher, that the people do need novels and dramas and paintings and poems.").

90 Lillian R. BeVier, The First Amendment and Political Speech: An Inquiry Into the Substance and Limits of the Principle, 30 STAN. L. REV. 299, $311-322$ (1978) [hereinafter BeVier, Substance and Limits]. Like Bork, BeVier went so far as to argue that a Meiklejohnian approach to the First Amendment protected too much speech. Id. at $317 \mathrm{n}$.70 ("I am 
litical speech, she said, called into question the very notion that the First Amendment was designed primarily to protect political speech and was unwise given the "weakness of the case" for protecting expression based on "nonpolitical speech values." According to BeVier, the only First Amendment value advanced by protecting nonpolitical speech was individual self-fulfillment, a principle that "on close analysis . . lacks sound justification."

Specifically examining defamation law, BeVier had no problem with the Court's decisions in New York Times, Curtis Publishing Co., and Walker because applying a constitutional standard to "speech about public figures involved in matters of public interest and ... speech about public officials' conduct of public business ... does not necessarily distort the political speech principle; it merely responds to the view that speech about public figures is an effective equivalent of political speech. ${ }^{993} \mathrm{BeVier}$, however, argued that a majority of the Court should have embraced Justice Brennan's opinion in Rosenbloom, which extended constitutional protection to "all discussion and communication involving matters of public or general concern." 94

BeVier was highly critical of the Gertz Court's holding that "so long as they do not impose liability without fault, the States may define for themselves the appropriate standard of liability for a publisher or broadcaster of defamatory falsehood injurious to a private individual." 95 Even though BeVier admitted this level of protection was "essentially quite low," she criticized the holding because granting all defamation constitutional protection was unexplainable by the political speech principle. ${ }^{97}$ Writing seven years before the Court's decision in Dun \& Bradstreet, BeVier did not address what standard should apply in private-figure-private-issue cases, although she later called all of the Court's post-New York Times defamation decisions "for the most part an undistinguished lot of surprisingly trivial cases clothed in ill-fitting but by now wholly

unwilling to extend the ambit of first amendment protection as far as Meiklejohn"). BeVier's stance is probably in reaction to Meiklejohn's later writings in which he supported extending First Amendment protection to literary and artistic works. See Meiklejohn, Absolute, supra note 79, at 263 ("I believe, as a teacher, that the people do need novels and dramas and paintings and poems.").

91 BeVier, Substance and Limits, supra note 90, at 311.

92 Id. at, 318.

93 Id. at 348-49.

$94 I d$. at 349 (quoting Rosenbloom v. Metromedia, Inc., 403 U.S. 29, 44 (1971)). Although Brennan never explicitly stated so, BeVier argued that "Brennan also seem[ed] to indicate that he would limit constitutional protection to "matters of public or general concern." Id. at 349 n.229 (1978) (citing Gertz v. Robert Welch, Inc., 418 U.S. 323, 361 (1974) (Brennan, J., dissenting)).

95 Gertz v. Robert Welch, Inc., 418 U.S. 323, 347(1974) (footnote omitted).

96 BeVier, Substance and Limits, supra note 90, at 351.

97 Id. at 351-52. 
conventional-seeming First Amendment garb." ${ }^{98}$

More recently, Professor James Weinstein contended that a political speech approach best explained the Court's freedom of expression doctrine and was the most "normatively attractive," noting that as recently as 2011 , in Snyder v. Phelps, ${ }^{100}$ the distinction between political and non-political speech "proved crucial." Weinstein would extend protection to speech that does not involve "a speaker's right of democratic participation" if regulation of such speech "unduly interferes with the audience's interest in receiving information needed to develop informed views on public policy matters." ${ }^{102} \mathrm{He}$ also supported a right of access to information if it contributed to a citizen's right to engage in self-government. ${ }^{103}$

Weinstein, however, was unwilling to extend protection to other types of speech that had no connection to the political process. ${ }^{104}$ Although, as noted above, a majority of the Supreme Court has never declared private defamatory speech wholly unprotected by the First Amendment, ${ }^{105}$ Weinstein categorically declared, "[I]f the speech addresses a purely private concern, then no First Amendment limitations restrain the normal operation of defamation law."106 To support this assertion, Weinstein cited the Dun \& Bradstreet plurality opin-

98 Lillian R. BeVier, Intersection and Divergence: Some Reflections on the Warren Court, Civil Rights, and the First Amendment, 59 WASH. \& LEE L. REV. 1075, 1084 (2002). BeVier cited Dun \& Bradstreet as an example of the Court's unfortunate willingness to place constitutional constraints on common law. Id. at $1084 \&$ n.52.

99 James Weinstein, Participatory Democracy as the Central Value of American Free Speech Doctrine, 97 VA. L. REV. 491, 491 (2011). According to Weinstein, "despite the lip service that the Court has paid to the marketplace-of-ideas rationale, the actual decisions show[ed] that the Court protects speech promoting the marketplace of ideas much less rigorously than it protects speech by which we govern ourselves." Id. at 502 (footnote omitted).

100 Snyder v. Phelps, 131 S. Ct. 1207 (2011).

101 Weinstein, supra note 99, at 495.

102 Id. at 500 (footnote omitted). Weinstein cited Citizens United v. FEC, 130 S. Ct. 876 (2010), as an example of the Court striking down a regulation on the basis of the listener's right to receive information independent of a speaker's right to communicate information. Although a corporation has no need for the legitimating function of political participation, Weinstein argued the Court's decision could be supported by the political speech principle by focusing on the audience's interest in hearing corporate messages unrestricted by campaign finance laws. Weinstein, supra note 99, at 500-01.

103 Weinstein, supra note 99, at 501 (citing Globe Newspaper Co. v. Superior Court, 457 U.S. 596, 604 (1982)).

104 Id. at $499 \mathrm{n} .45$. While Weinstein offered an argument why the political speech principle could be understood to protect non-ideational art, he wrote he was not satisfied that these arguments adequately explained the "rigorous protection" afforded such expression. Id.; see also James Weinstein, Hate SPEech, Pornography aNd the Radical ATtaCk on FreE SPEECH DOCTRINE 15-16 (1999).

105 See supra notes $72-75$ and accompanying text.

106 Weinstein, supra note 99, at 494 (footnote omitted). 
ion-which, in fact, said that "such speech is not totally unprotected by the First Amendment"107 — and Justice Burger's and Justice White's concurring opinions, in which they argued that constitutional protections should not apply to private speech. ${ }^{108}$

Professor Robert Post adopted a more nuanced stance. Like Bork, BeVier, and Weinstein, Post was critical of the "self-fulfillment" value of freedom of expression. $^{109}$ Although Post acknowledged this value "has deep roots in American constitutionalism," he wrote that it "[wa]s not especially helpful in explaining the actual scope of the First Amendment; nor, . . . in normatively explaining what th[at] scope [should] be."110 In addition, Post felt that the discovery of truth-or the "marketplace of ideas" metaphor-was also unable to explain First Amendment doctrine." According to Post, "The best possible explanation of the shape of First Amendment doctrine is the value of selfgovernance." 12 Post, however, parted ways with Meiklejohn and Bork because they identified political speech with "collective decision making" while he identified it with "self-governance." 113

Thus, Post advocated a separate, Habermasian approach to First Amendment

107 Dun \& Bradstreet, Inc. v. Greenmoss Builders, Inc., 472 U.S. 749, 760 (1985) (emphasis added).

108 Id. at 763-64 (Burger C.J., concurring); id. at 774 (White, J., concurring).

109 Robert Post, Participatory Democracy and Free Speech, 97 VA. L. ReV. 477, 479 (2011) ("There is no doubt that this form of liberal autonomy has deep roots in American constitutionalism, and it is clear that its influence can be detected in First Amendment doctrine. But in my view this value is not especially helpful in explaining the actual scope of the first Amendment; nor, in my view, is it particularly helpful in normatively explaining what this scope ought to be.").

110 Id. at 479. Post argued that because "autonomy" applies to actions as well as speech, there "are many situations in which the autonomy of a speaker conflicts with the autonomy of an audience," and "there are many situations in which the autonomy of a speaker and the harm done by the speech remain constant," and yet First Amendment protections differ. Consequently, individual self-fulfillment could not explain free speech jurisprudence. $I d$. at 479-80.

111 Id. at 478-79. According to Post, because the First Amendment "recognizes no such thing as a 'false' idea," the First Amendment was unsuited to the discovery of truth or the creation of new knowledge. Id. at 478. Post wrote, "The creation of knowledge ... depends upon practices that continually separate the true from the false, the better from the worse." Id. at 478-79.

112 Id. at 481 .

113 Id. at 482. Post explained:

Democracy involves far more than a method of decision making; at root democracy refers to the value of authorship. Democracy refers to a certain relationship between persons and their government. Democracy is achieved when those who are subject to law believe that they are also potential authors of law. Elections and other mechanisms that we ordinarily associate with democratic decision making are simply institutions designed to maximize the likelihood that this relationship obtains.

Id.; see also Robert Post, Democracy and Equality, 603 ANNALS AM. ACAD. POL. \& Soc. SCI. 24, 26 (2006). 
claims. ${ }^{114}$ Post contended the First Amendment should protect "public discourse"-or speech that contributes to the formation of public opinion-rather than "political speech." 11 Post wrote: "Public discourse includes all communicative processes deemed necessary for the formation of public opinion. Art and other forms of nocognitive [sic], nonpolitical speech fit comfortably within the scope of public discourse."116 Although Post did not protest that standard First Amendment doctrine would grant "little or no protection" to a defendant who defamed a private person about a private matter, ${ }^{117}$ his definition of what constitutes a private matter would be much narrower than that of Bork, BeVier or Weinstein. ${ }^{18}$ Whereas Weinstein concentrates on the content of speech, Post concentrates on context. ${ }^{119}$

In addition to these more general normative debates over the proper scope of the First Amendment, scholars have also specifically examined the publicspeech-private-speech distinction in defamation law. In the wake of Dun \& Bradstreet, several authors were critical of Powell's attempt to reconcile the case with Gertz; ${ }^{120}$ some found fault with the use of subject matter tests, ${ }^{121}$ or

114 See generally JÜRgen Habermas, Theories of CoMmuniCative ACTION (1981). Much of this difference relies on whether one focuses on the importance of the speaker-the Habermasian approach-or the listener-the Meiklejohnian approach. Compare JÜRGEN Habermas, The Structural Transformation of the Public Sphere: An InQUiry into a CATEGORY OF BOURGEOIS SOCIETY 1-26 (1962) (theorizing that democratic legitimation occurs specifically through a deliberative process of communication in the public sphere), with MEIKLEJOHN, FREE SPEECH, supra note 1, at 25 (writing the First Amendment's "ultimate interest is not the words of the speakers, but the minds of the hearers" and the First Amendment "does not require that . . . every citizen shall take part in public debate" nor that "everyone ... have the opportunity to do so").

115 Post, supra note 109 , at 484.

116 Id. at 486.

$117 \mathrm{Id}$. at 480 .

118 Id. at $485-87$ (discussing expression, such as art, that would contribute to public discourse and thus qualify for First Amendment protection).

119 Weinstein placed more emphasis on the content of the speech, focusing on the classic definition of "matters of public concern." Post wrote that identical content might or might not be constitutionally protected given the context in which the speech occurred. James Weinstein, supra note 99, at 493 n.9 ("One difference is that, in determining whether an individual instance of speech is part of public discourse, I place somewhat greater emphasis on the content of the speech (that is, whether or not it is on a matter of public concern), while Post focuses more on its context (that is, whether or not the expression occurs in a setting essential to democratic self-governance.").

120 See, e.g., Gerald R. Smith, Of Malice and Men: The Law of Defamation, 27 VAL. U. L. REv. 39, 40 (1992); Michael Green, Comment, Dun \& Bradstreet v. Greenmoss: Cutting Away the Protective Mantle of Gertz, 37 Hastings L. J. 1171, 1172 (1986).

121 See, e.g., Robert E. Drechsel, Defining "Public Concern" in Defamation Cases Since Dun \& Bradstreet v. Greenmoss Builders, 43 FED. CoMM. L.J. 1, 1 (1990); Don Lewis, Dun and Bradstreet, Inc. v. Greenmoss Builders, Inc., Philadelphia Newspapers, Inc. v. Hepps, and Speech on Matters of Public Concern: New Directions in First Amendment Defamation Law, 20 IND. L. REV. 767, 768 (1987). 
noted the case raised questions about "the reach of its rationale." 122 However, most of the empirical work has focused on determining what constitutes a matter of public concern ${ }^{123}$ or who qualifies as a public figure. ${ }^{124}$ Some authors have questioned whether Dun \& Bradstreet and Hepps signaled the Court's willingness to return private-private libel cases to the common law and allow courts to apply a strict liability standard in such cases. ${ }^{125}$ As Rodney Smolla noted in 1988, the fractured Dun \& Bradstreet Court left it unclear "whether all the Gertz rules, including the no liability without fault rule, are completely outside of first amendment restrictions when the speech is not of 'public concern." $" 126$

In a previous article focusing on the impact of Dun \& Bradstreet, ${ }^{127}$ we found a number of courts, including eight U.S. courts of appeals, fourteen U.S. district courts, and appellate courts in twenty-two states, had addressed how the First Amendment applies to private-private defamation cases. ${ }^{128}$ Based on that analysis, we concluded courts have "run the gamut from assertions that Dun \& Bradstreet swept away all First Amendment requirements in privateprivate suits to unequivocal declarations that the case affected nothing but the fault requirement for presumed and punitive damages." 129 Even after the First Circuit's 2009 refusal to rule that truth is an absolute First Amendment defense in private-private defamation cases, ${ }^{130}$ few scholars examined the deconstitutionalization of private speech. ${ }^{131}$ This study updates this important development in First Amendment law, which has generated considerable normative debate but little recent empirical analysis.

\footnotetext{
122 Nat Stern, Private Concerns of Private Plaintiffs: Revisiting a Problematic Defamation Category, 65 Mo. L. REv. 597, 604 (2000); see also Lewis, supra note 121, at 774-75; Smith, supra note 120, at 57; Seth Goodchild, Note, Media Counteractions: Restoring the Balance of Modern Libel Law, 75 GEo. L. J. 315, 317 (1986).

123 See, e.g., Drechsel, supra note 121, at 1; Arlen W. Langvardt, Public Concern Revisited: A New Role for an Old Doctrine in the Constitutional Law of Defamation, 21 VAL. U. L. REV. 241 (1987); Smith, supra note 120, at 39; Stern, supra note 122, at 599.

124 See, e.g., Amy Kristin Sanders, Defining Defamation: Plaintiff Status in the Age of the Internet, 1 J. MEDIA L. \& ETHICS 155 (2009).

125 See, e.g., Joseph H. King, Jr., Deus Ex Machina and the Unfulfilled Promise of New York Times v. Sullivan: Apply the Times for All Seasons, 95 KY. L.J. 649, 696 (2007); Lewis, supra note 121, at 782; Smith, supra note 120, at 57.

126 RODNEY A. SMOLla, LAW OF DEFAMATION $\S 1.05[4]$ (1988).

127 Dun \& Bradstreet, Inc. v. Greenmoss Builders, Inc., 472 U.S. 749 (1985).

128 Ruth Walden \& Derigan Silver, Deciphering Dun \& Bradstreet: Does the First Amendment Matter in Private Figure-Private Concern Defamation Cases?, 14 CoMM. L. \& POL'Y 1, 15 (2009).

129 Id. at 16.

130 Noonan v. Staples, Inc., 561 F.3d 4, 7 (1st Cir. 2009).

131 But see Lindsee Gendron, Noonan v. Staples: Libel Law's Shocking New Precedent and What it Means for the Motion Picture Industry, 7 U. DENV. SPORTS \& ENT. L.J. 20 (2009); Recent Case, 123 HaRv. L. Rev. 784, 787-90 (2010).
} 


\section{DECONSTITUTIONALIZATION OF PRIVATE SPEECH IN THE LOWER COURTS}

\section{A. Falsity and Truth in Private-Person-Private-Issue Defamation Cases}

The most startling example of deconstitutionalizing the law of private libel came in 2009, when the U.S. Court of Appeals for the First Circuit ruled that a private plaintiff could collect damages for the publication of true defamatory statements about a matter of private concern if those statements were published with ill will or malevolent intent. ${ }^{132}$ Noonan v. Staples began in 2006 when Alan S. Noonan was fired from his job as a Staples salesman for violating the company's travel and expense policy and code of ethics. ${ }^{133}$ Anomalies in Noonan's expense reports (including claiming \$1129 for an \$11.29 meal at an airport McDonald's) were uncovered through an audit of a sample of sixty-five employees' expense reports undertaken after the company discovered another employee had embezzled money through fraudulent expense reports. ${ }^{134}$ The day after Noonan was fired, Staples' Executive Vice-President Jay Baitler sent an email to approximately 1500 Staples employees stating, "It is with sincere regret that I must inform you of the termination of Alan Noonan's employment with Staples. A thorough investigation determined that Alan was not in compliance with our [travel \& expense] policies."135 The email went on to emphasize the importance of understanding and complying with the company's policies. ${ }^{136}$ Noonan sued for defamation based on the email, along with other claims related to his firing.

Noonan v. Staples has a long and complicated procedural history. In 2007, the U.S. District Court for the District of Massachusetts granted Staples's motion for summary judgment on all claims, ${ }^{137}$ and Noonan appealed. On its first pass at the case in 2008, the First Circuit affirmed the trial court's decision completely, but, on rehearing in 2009 , the panel withdrew its first opinion and kept Noonan's defamation claim alive, remanding that claim for trial. ${ }^{138} \mathrm{~A}$ month later the First Circuit denied Staples's petition for rehearing. ${ }^{139}$

\footnotetext{
132 Noonan v. Staples, Inc., 556 F.3d 20, 29, reh'g denied, 561 F.3d 4 (1st Cir. 2009).

133 Noonan v. Staples, Inc., No. 06-CV-10716-MEL, 2007 WL 6064454, at *1 (D. Mass. June 28, 2007). Noonan, a Florida resident, initially filed suit in a Massachusetts state court against Staples, a Massachusetts corporation. Staples then removed the case to federal court because of diversity of citizenship. Noonan v. Staples, Inc., 556 F.3d 20, 24, reh'g denied, 561 F.3d 4 (1st Cir. 2009).

134 Noonan, 556 F.3d at 23.

135 Noonan, 2007 WL 6064454 , at *1.

136 Id.

137 Id.

138 Noonan, 556 F.3d at 22-3, 36.

139 Noonan v. Staples, Inc., 561 F.3d 4 (1st Cir. 2009). The court also construed Staples's
} 
When the Massachusetts federal district court initially dismissed Noonan's libel claim, it did so because it found the statements in the email to be true. ${ }^{140}$ All three times the First Circuit reviewed the case, it never disputed that the email was true: Noonan was fired for violating the company's travel and expense policy. ${ }^{141}$ On rehearing, however, the First Circuit focused on a 1902 Massachusetts statute that provides truth is a defense to libel "unless actual malice is proved." 142 The First Circuit said the term "actual malice" in the statute could not possibly refer to constitutional actual malice because the statute was enacted sixty-two years before the U.S. Supreme Court defined actual malice as knowledge of falsity or reckless disregard for the truth. ${ }^{143}$ Additionally, applying a knowing or reckless falsification standard to true statements, the court reasoned, made no sense. ${ }^{144}$ The federal appellate court then turned to a 1903 Massachusetts Supreme Judicial Court opinion ${ }^{145}$ to determine that under state law a true statement published with "ill will" or "malevolent intent" "was actionable in private figure-private issue libel cases. ${ }^{146}$ A jury, the First Circuit said, could find "ill will" because 1) "in Baitler's twelve years with the company, he had never previously referred to a fired employee by name in an e-mail or other mass communication;"147 2) Baitler did not send around an email about the employee who had been fired for embezzlement, which could lead a jury to conclude he had "singled out Noonan to detract attention away from the [earlier] scandal" because Baitler had been the supervisor of the embezzling employee; ${ }^{148}$ and 3 ) sending the email to about $1500 \mathrm{em}$ ployees, some of whom might not even travel for their jobs, could be deemed excessive publication. ${ }^{149}$

Remarkably, the First Circuit never addressed the constitutionality of the 1902 Massachusetts statute in its opinion, apparently because Staples's attorneys never raised the issue. ${ }^{150}$ Indeed, in its entire opinion, the court cited only two U.S. Supreme Court libel cases, one of which was to identify the post-

petition as a petition for panel rehearing and a request to certify to the Massachusetts Supreme Judicial Court the question of the constitutionality of the state law at issue in the case. Those were also denied. Id. at 7.

140 Noonan, 2007 WL 6064454, at *2.

141 See Noonan, 556 F.3d at 26; Noonan, 561 F.3d at 7.

142 MASS. GeN. LaWs ch. 231 \$ 92 (2009).

143 Noonan, 556 F.3d at 29.

144 Id. at 28.

145 Conner v. Standard Publ'g Co., 67 N.E. 596 (Mass. 1903).

146 Noonan, 556 F.3d at 29 (discussing Conner v. Standard Publ'g Co., 67 N.E. 596, 598

(Mass. 1903)).

147 Id. at 30 .

148 Id.

149 Id. at 31 .

150 See Noonan v. Staples, Inc., 561 F.3d 4, 6 (1st Cir. 2009). 
1964 definition of the term "actual malice."151 The second citation occurred in the court's discussion of the illogicality of using the modern definition of actual malice. ${ }^{152}$ However, its use could be viewed as an oblique reference to the question of whether the First Amendment applies to private libel. Citing Hepps, the First Circuit said, "[S]tatements of public concern [are] an area in which defamatory true statements are not actionable."153 The court, however, failed to take the next step of either discussing or supporting the proposition that, under Hepps, true statements of private concern are actionable.

When Staples petitioned the court for rehearing en banc, the company sought to challenge the constitutionality of the Massachusetts statute that allowed liability for true but maliciously published defamatory statements. ${ }^{154}$ Although the First Circuit said it would not consider the constitutional challenge because Staples had not raised the issue in its initial brief, the court addressed the issue briefly in the rehearing. ${ }^{155}$ The constitutional issue, the court said, was not "so clear that the panel should have acted sua sponte to strike down a state statute, without the required notice to the state attorney general." 156 The court continued, "Staples still [did] not cite a case for the proposition that the First Amendment does not permit liability for true statements concerning matters of private concern."157 However, Staples did cite a 1975 ruling by the Massachusetts Supreme Judicial Court, but the panel found the case "did not hold that truth is an absolute defense in private concern cases, but rather that a private figure may recover for a negligently made defamatory falsehood in a case of public concern."

The First Circuit then went on to quote Hepps-"[T]he Supreme Court has stated that as to matters of private concern, the First Amendment does 'not necessarily force any change in at least some of the features of the commonlaw landscape" - and the Dun \& Bradstreet statement on "the reduced constitutional value of speech involving no matters of public concern." "159 Finally, the First Circuit said that when the Massachusetts Supreme Judicial Court

151 Noonan, 556 F.3d at 28 (quoting Cantrell v. Forest City Publ'g Co., 419 U.S. 245, 251 (1974) (quoting New York Times v. Sullivan, 376 U.S 254, 280 (1964))). Why the court chose to quote Cantrell, a false light invasion of privacy case quoting New York Times, instead of quoting New York Times directly is not apparent.

152 Id. at 29 (citing Phila. Newspapers, Inc. v. Hepps, 475 U.S. 767, 768-69 (1986)).

153 Id. at 29 (citing Phila. Newspapers, Inc. v. Hepps, 475 U.S. 767, 768-69 (1986)).

154 Noonan, 561 F.3d at 6.

155 Id. at 6-7.

156 Id. at 6.

157 Id. at 6-7.

158 Id. at 7 (discussing Stone v. Essex Cnty. Newspapers, Inc., 330 N.E.2d 161, 164 (1975)) (emphasis in original).

${ }_{159}$ Id. at 7 (quoting Phila. Newspapers, Inc. v. Hepps, 475 U.S. 767, 775 (1986) and Dun \& Bradstreet, Inc. v. Greenmoss Builders, Inc., 472 U.S. 749, 761 (1985)). 
ruled on the truth-with-malice statute in 1998, it held the law invalid only as applied to truthful defamatory statements concerning "matters of public concern." 160 Staples's petition for rehearing was denied, and the case remanded for trial. In October 2009, a Boston jury found in favor of Staples, ${ }^{161}$ but, of course, that jury verdict did nothing to disturb the First Circuit's decision to permit potential liability for true, malicious, defamatory statements.

A little more than a year before the First Circuit's surprising ruling in Noonan, a Massachusetts state trial court had ruled that even in a privatefigure-private-issue defamation case, the defendant bore the burden of proving the falsity of the allegedly defamatory statement. ${ }^{162}$ McNamara $v$. Costello began with a letter sent by Patrick Costello, special counsel for the treasurer/tax collector of the Town of Millville, Massachusetts, to Susan McNamara's attorney and to the City of Millville Tax Collector and Treasurer. ${ }^{163} \mathrm{McNamara}$, the town clerk and assistant assessor for Millville, contended the letter accused her of criminal conduct in the acquisition of two parcels of land. ${ }^{164}$ The parties disagreed over whether the plaintiff was a public figure and whether the letter addressed a matter of public concern. ${ }^{165}$ Because the court was ruling on the defendant's summary judgment motion, it construed all disputed facts in the light most favorable to the plaintiff and, consequently, treated "McNamara as a private figure and the statement a matter of private concern for purposes of deciding the motion for summary judgment." 166 Citing the same Massachusetts Supreme Judicial Court opinion the First Circuit later used to support the proposition that truth was not necessarily an absolute defense in a private issue libel case in Massachusetts, the trial court declared, "Even as a private figure, McNamara would still bear the burden, at trial, of proving that Costello's statement was a defamatory falsehood."167

Which court was correct in its interpretation of the Massachusetts high court's ruling in Stone v. Essex County Newspapers, Inc. ${ }^{168}$ That is a difficult question to answer, primarily because the timing of Stone was one year after the Supreme Court repudiated focus on the subject matter of the defamatory

160 Id. at 7 (citing Shaari v. Harvard Student Agencies, 691 N.E.2d 925, 929 (Mass. 1998)).

161 David Ardia, Case That Upended Truth Defense in Libel Actions Ends with Jury Verdict for Defendant, Citizen MEDIA L. Project (Oct. 15, 2009, 3:20 PM), http://commcns.org/10wARQx.

162 McNamara v. Costello, No. 07881 B, 2008 WL 142723 (Mass. Super. Jan. 2, 2008).

163 Id. at *1.

164 Id. at $* 1-2$.

165 Id. at $* 3$ n.4. The court used the term "public figure" rather than "public official" even though McNamara was a town official.

$166 I d$.

167 Id. (citing Stone v. Essex Cnty. Newspapers, Inc., 367 Mass. 849, 858 (1975)).

168 Stone v. Essex Cnty. Newspapers, Inc., 330 N.E.2d 161 (Mass. 1975). 
report in Gertz, ${ }^{169}$ and nine years before the Court resurrected subject matter consideration in Hepps. ${ }^{170}$ In fact, it was the Supreme Court's retreat from subject matter consideration in Gertz that brought the Stone case back to the Massachusetts high court for a rehearing. When the supreme judicial court first heard Stone, in May 1974, one month before Gertz was decided, it based its ruling on Rosenbloom ${ }^{171}$ and held that plaintiff's status was immaterial given that the subject of the report, "a public prosecution," was "one of public interest under the Metromedia case."172

Acknowledging that Gertz prompted its decision to rehear the case, ${ }^{173}$ the Massachusetts Supreme Judicial Court first laid out the constitutional rules of libel post-Gertz. ${ }^{174}$ Because the trial court had not resolved whether Stone, who held a position in local government, was a public official or a private figure, the court listed the fault requirements for both before remanding the case for retrial. ${ }^{175}$ Here is where the disputed quotation occurred: "Accordingly, we hold that private persons, as distinguished from public officials and public figures, may recover compensation on proof of negligent publication of a defamatory falsehood." 176 This is the quote Staples argued proved that truth is an absolute defense in defamation cases and that the McNamara court held required falsity in private-private cases, ${ }^{177}$ but it's also the quote the First Circuit said proved no more than that falsity was required in cases involving matters of public concern. ${ }^{178}$ Because the First Circuit refused to certify to the state supreme court the question of the interpretation of the Massachusetts truth-with-malice statute, ${ }^{179}$ it is impossible to know how today's state high court justices would interpret the words of their predecessors.

Adding to the concern generated by the First Circuit's ruling in Noonan is the fact that at least eighteen other states have constitutional or statutory provisions that permit civil liability and/or criminal punishment for truthful defamatory statements. ${ }^{180} \mathrm{~A}$ few, such as the Massachusetts law, are written in the

169 Gertz v. Robert Welch, Inc., 418 U.S. 323 (1974).

170 Phila. Newspapers, Inc. v. Hepps, 475 U.S. 767 (1986).

171 Rosenbloom v. Metromedia, Inc., 403 U.S. 29 (1971).

172 Stone, 330 N.E.2d at 167.

173 Id. at 167.

174 Id. at 167-69.

175 Id. at $169-74$.

176 Id. at 168

177 McNamara v. Costello, No. 07881B, 2008 WL 142723, at *3 n.4 (Mass. Super. Jan. 2, 2008) (citing Stone v. Essex Cnty. Newspapers, Inc., 367 Mass. 849, 858 (1975)).

178 Noonan v. Staples, Inc., 561 F.3d 4, 7 (1 st Cir. 2009) (citing Stone v. Essex Cnty. Newspapers, Inc., 330 N.E.2d 161, 164 (1975)).

179 Id. at 7 .

180 See constitutional provisions for Florida, FLA. CoNST. art. I, $\S 4$; Illinois, ILL. CoNST. art. I, § 4; Kansas, KAN. ConST. Bill of Rights § 11; Mississippi, MIss. ConST. art. III, § 13; Nebraska, Neb. ConST. art. I, $\S 5$; Nevada, Nev. ConsT. art. I, § 9; North Dakota, N.D. 
negative, defining malicious motives as an exception to the truth defense. ${ }^{181}$ The majority, however, are affirmative declarations requiring truth "with good motives and for justifiable ends."182

This study did not discover any cases other than Noonan in which courts held that libel defendants could be liable for publishing the truth. However, revised jury instructions for use in civil cases in Florida, approved by the state supreme court in March 2010, clearly open the door for more such cases. ${ }^{183}$ The jury instructions recognize three categories of defamation cases: (1) those in which the plaintiff is a public person and the defendant is "a member of the press or broadcast media publishing on a matter of public concern;" (2) those in which the plaintiff is a private person and the defendant is "a member of the press or broadcast media publishing on a matter of public concern;" and (3) "all other claims," which includes private figure plaintiffs, nonmedia defendants, and matters of private concern. ${ }^{184}$

In the last category of defamation cases - private-plaintiff-private-issue and nonmedia defendants - the instructions indicated that "Florida's truth and good motives defense" applies. ${ }^{185}$ Although the portion of the jury instructions deal-

CONST. art. I, § 4; Oklahoma, OKLA. CONST. art. II, §22; Rhode Island, R.I. CONST. art. I, § 20; South Dakota, S.D. ConST. art. VI, $\S 5$; West Virginia, W. VA. ConST. art. III, $\S 8$; Wyoming, WYo. CONST. art. I, $\$ 20$; see statutory provisions for Delaware, DEL. CODE ANN. tit. 10, 3919 (West 1974); Idaho, IDAHO. CODE ANN. § 18-4803 (West 2004); Louisiana, LA. REV. STAT. ANN. § 14:47 (2007); Mississippi, Miss. CODE ANN. § 97-3-57 (West 2011); Nebraska, Neb. Rev. Stat. ANN. \& 25-840 (LexisNexis 2004); Nevada, Nev. Rev. Stat. ANN. § 200.510 (LexisNexis 2012); New Mexico, N.M. STAT. ANN. § 30-11-1 (1978); Oklahoma, OkLa. Stat. ANN. tit. 12, $\S 1441$ (West 2002), OKLA. Stat. AnN. tit. 21, $\$ 771$ (West 2010), and OKLA. STAT. ANN. tit. 21, $\$ 774$ (West 2010); Pennsylvania, 42 PA. Cons. STAT. ANN. § 8342 (West 1970); Rhode Island, R.I. GeN. LAWS ANN. § 9-6-9 (West 1956); and Wisconsin, Wis. STAT. ANN. $\$ 942.01$ (West 1957).

181 MASS GEN. LAWS ANN. ch. 278, § 8 (West 1958); see also R.I. CONST. art. I, § 20 (" $[\mathrm{A}] \mathrm{nd}$ in all trials for libel, both civil and criminal, the truth, unless published from malicious motives, shall be sufficient defense to the person charged.") (emphasis added).

182 E.g., ILL. CONST. art. I, § 4; WIS. STAT. ANN. § 942.01 (West 1957).

183 In re Standard Jury Instructions in Civil Cases, 35 So. 3d 666 (Fla. 2010).

184 Id. at 733 . The references to media defendants versus nonmedia defendants illustrate another major area of uncertainty in defamation law: The extent to which First Amendment protections announced by the Supreme Court apply to nonmedia defendants. As noted above, much of this uncertainty can be traced to Justice Powell's majority opinion in Gertz and subsequent cases. See id. at 733-735. The Notes on Use on Defamation Instructions accompanying the Florida jury instructions recognize this uncertainty, but conclude that because neither the United States Supreme Court nor the Florida Supreme Court has ever ruled that a media publication was not a matter of public concern, the distinction based on defendant's status is warranted. For a discussion of the distinction between media and nonmedia defendants in lower courts, see infra notes 264-300 and accompanying text. See also Walden \& Silver, supra note 128, at 15; Rebecca Phillips, Comment, Constitutional Protections for Nonmedia Defendants: Should There Be a Distinction Between Larry King and You?, 33 CAMPBELl L. REV. 173, 176-182 (2010).

185 Standard Jury Instructions, 35 So. 3d at 725. 
ing with the truth and good motives defense provides an explanation of what constitutes substantial truth, it does not define "good motives." ${ }^{186}$ Nonetheless, a subsequent section dealing with qualified privilege for communications of mutual interest does define "improper motives": "if one's primary motive and purpose in making the statement is to gratify one's ill will, hostility and intent to harm the other." 187 The Notes on Use on Defamation Instructions mention the uncertainty that surrounds the constitutionality of punishing the publication of true statements. Citing Florida Star v. B.J.F., ${ }^{188}$ the instructions state:

Note that the United States Supreme Court has reserved the question whether in a First Amendment context it can ever be actionable, whatever the motive, to speak the truth. Pending a Florida decision explaining its meaning and effect, the committee assumes that "the truth and good motives" provision tolerates at least as wide a range of motives for speaking the truth as the common law tolerates for speaking untruthfully in a privileged situation. ${ }^{189}$

None of the post-1985 Florida cases identified for this study discussed the truth/falsity issue. ${ }^{190}$ Thus, it is unknown what the Florida courts would do if faced with a case such as Noonan. Indeed, truth/falsity did not generate much discussion at all in the opinions reviewed, perhaps because it was seldom an issue in dispute. In the few cases in which courts did discuss truth/falsity, most simply followed the Hepps rule. In doing so, many courts cited only state precedents and not Hepps, noting that defendants in private-private cases could raise truth as a defense. ${ }^{191}$ In a few cases, courts simply declared that fal-

186 Id. at 730 (defining a substantially true statement as one whose "substance or gist conveys essentially the same meaning that the truth would have conveyed," but failing to define "good motives").

187 Id. at 730-31; see also id. at 735.

188 Florida Star v. B.J.F., 491 U.S. 524, 533 (1989) (holding that the First Amendment prohibits punishment of the publication of truthful information lawfully obtained absent a "state interest of the highest order.").

189 Standard Jury Instructions, 35 So. 3d at 735 (citation omitted).

190 All state and federal cases in the Westlaw database decided after 1985-the year in which Dun \& Bradstreet v. Greenmoss Builders, 472 U.S. 749 (1985), was decided-were searched using the term "libel or defamation or slander and 'private figure' or 'private person' or "private individual."' A secondary search of the cases identified using the primary search term was then conducted using the term "'matter of private concern' or 'not matter of public concern' or 'private interest' or 'not public interest' or 'private issue' or 'not public issue' or 'matters not of public concern' or 'does not involve matters of public concern' or 'a matter not of public concern' or 'not a matter of public concern' or 'matters of private concern' or "not matters of public concern." "The cases identified by the secondary search were then manually searched to identify opinions addressing the standards to be applied in defamation cases involving private individuals and matters of private concern. This search did not find any Florida defamation cases dealing with the issue.

191 See, e.g., Williams v. Detroit Bd. of Educ., 306 Fed. App'x. 943, 946-47 (6th Cir. 2009); Ogle v. Hocker, 669 F. Supp. 2d 795, 799 (E.D. Mich. 2009); Patrick v. Cleveland Scene Pub. LLC, 582 F. Supp. 2d 939, 947 (N.D. Ohio 2008); Mackin v. Cosmos Broad., Inc., No. 3:05-CV-331-H, 2008 WL 2152188, at *2 (W.D. Ky. May 21, 2008); Super Future Equities, Inc. v. Wells Fargo Bank Minn., N.A., 553 F. Supp. 2d 680, 691-92 (N.D. Tex. 
sity was an element of the offense, making it unclear whether the courts were indicating that all plaintiffs, regardless of subject matter, were required to prove falsity..$^{192}$ Nonetheless, the Supreme Court's statements raising doubts about First Amendment protection for private speech, coupled with a United States Court of Appeals ruling and laws in nineteen states allowing civil and/or criminal liability for true defamatory statements, certainly keep the possibility alive that defamation defendants can be punished for speaking the truth. ${ }^{193}$

\section{B. Fault in Private-Person-Private-Issue Defamation Cases}

Several courts, including one United States Court of Appeals and three state supreme courts, have specifically stated that constitutional fault requirements are inapplicable to private-private defamation cases or have more broadly stated that private-privates cases trigger no constitutional scrutiny. In 1993, in Snead v. Redland Aggregates, the Court of Appeals for the Fifth Circuit concluded that Dun \& Bradstreet returned private-private defamation cases to the purview of the common law. ${ }^{194}$ Snead involved a press release regarding a lawsuit for misappropriation of trade secrets and breach of a confidential relationship between a Texas company and two British companies. ${ }^{195}$ Snead, chairman of Georgetown Railroad Company, issued a press release accusing the two British companies of "international theft," "industrial espionage" and "international piracy." 196

The court first determined that Redlands and its co-defendant, Standard Railway Wagon, were not public figures due to their relative anonymity in America. ${ }^{197}$ Such anonymity was a result of minimal past publicity, along with the fact that mining companies and railroad construction companies were not typically "household names." 198 Next, the court noted that, although international competition and industrial espionage "may be" matters of public concern, Snead's "speech does not concern an ongoing public debate about international competition and industrial espionage" and "was not aimed at enlightening the public." 199 Therefore, it was speech of private concern. ${ }^{200}$ In what

2008); Parrish v. Allison, 656 S.E.2d 382, $391-92$ (S.C Ct. App. 2007).

${ }_{192}$ See, e.g., Taylor Bldg. Corp. of America v. Benfield, 507 F. Supp. 2d 832, 838 (S.D.

Ohio 2007); Senna v. Florimont, 958 A.2d 427, 443 (N.J. 2008).

193 See supra notes 47-75, 132-191 and accompanying text.

194 Snead v. Redland Aggregates Ltd., 998 F.2d 1325, 1333-34 (5th Cir. 1993).

195 Id. at 1328.

196 Id.

197 Id. at 1330.

198 Id. at $1329-30$.

199 Id. at 1330.

200 Id. The court found that the speech in question "was speech solely in the individual interest of the speaker and its specific business audience." Id. (quoting Dun \& Bradstreet, 
would become an oft-cited and quoted statement, the court wrote: "[W]e believe that five Justices of the Dun \& Bradstreet Court supported common law standards for private/private cases. We therefore conclude that the Constitution imposes no minimum standard of fault in private/private libel cases." ${ }^{\text {201 }}$

Writing for a unanimous three-judge panel, Judge Jerry E. Smith, like Professor Weinstein, based his conclusion that private speech received no constitutional protection on Chief Justice Burger's and Justice White's separate concurrences in Dun \& Bradstreet. ${ }^{202}$ According to Judge Smith, the two justices reasoned that, in cases involving private figures, the Constitution does not impose a minimum standard of fault. ${ }^{203}$ Smith also wrote that Justice Powell's plurality opinion contained "strong hints" that Dun \& Bradstreet freed states to set their own rules in private-plaintiff-private-issue defamation cases. ${ }^{204}$ One such hint was a discussion of Justice Powell's "distaste" for the constitutionalization of private-private speech found in a single footnote. ${ }^{205}$ With no constitutional limitations applicable, the court of appeals panel turned to Texas law and concluded that "presumed damages are available in cases of libel per se without any showing of fault on the part of the defendant," but punitive damages required a showing of common law malice. ${ }^{206}$

In an unreported opinion, the Minnesota federal district court relied on only one sentence and a citation to a state court of appeals case, Weissman v. Sri Lanka Curry House ${ }^{207}$ to decide that Minnesota common law applies when the speech involves both a private plaintiff and a private issue. ${ }^{208}$ The court applied this rationale in a slander case that resulted from an allegation that the plaintiff

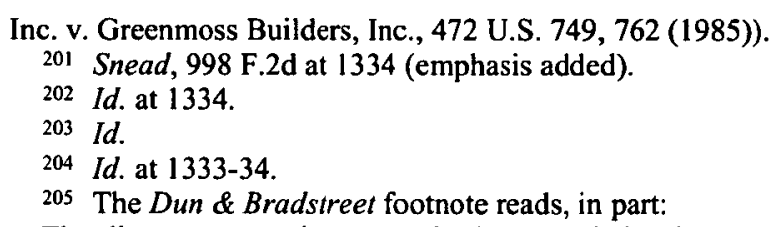

The dissent, purporting to apply the same balancing test that we do today, concludes that even speech on purely private matters is entitled to the protections of Gertz. . . . The dissent's "balance," moreover, would lead to the protection of all libels-no matter how attenuated their constitutional interest. ... The dissent would, in effect, constitutionalize the entire common law of libel.

Dun \& Bradstreet, 472 U.S. at 761 n. 7.

206 Snead, 998 F.2d at 1334-35. In a footnote, the court noted that it need not address whether the First Amendment imposed any fault requirement on the recovery of actual damages in a private-private case because the plaintiffs had not proven any actual damages. Such an approach does not stand to reason, given Gertz's holding that actual malice is required for presumed damages while only negligence is required for actual damages. Id. at $1331 \mathrm{n} .8$.

207 Weissman v. Sri Lanka Curry House, Inc., 469 N.W.2d 471 (Minn. Ct. App. 1991). Weissman, which dealt with protection for opinion, will be discussed in the next section.

${ }^{208}$ Kirckof v. Brown, No. CIV. 01-476 (JRTSRN), 2002 WL 31718394, at *5 (D. Minn. Nov. 27, 2002). 
"had a severe cocaine problem." 209 In another unreported opinion, the Northern Mariana Islands Supreme Court suggested in a footnote that the Supreme Court's ruling in Dun \& Bradstreet removed the fault requirements in privateprivate cases, "reviving the common law rule when private plaintiffs allege defamation on issues of private concern." ${ }^{210}$ However, it is unclear from the context whether the court was discussing all fault requirements or only those for presumed and punitive damages. ${ }^{21}$

In the United States District Court for the Middle District of North Carolina decision Sleem v. Yale University, a 1975 Yale alumnus sued the university for publishing a false "personal statement" about him in a class directory. ${ }^{212}$ The statement, which Sleem had not submitted, read: "I have come to terms with my homosexuality and the reality of AIDS in my life. I am at peace."213 The court began its discussion, cautiously stating that "the implication of Dun \& Bradstreet" is that the plaintiff in a private-figure-private-issue libel case is "no longer constitutionally required to prove fault." 114 Nonetheless, the court quickly abandoned caution and by the end of the paragraph asserted that "Dun \& Bradstreet allows the states to choose whether to allow presumed damages and impose liability without fault in cases involving private person plaintiffs and non-public issues."215

In addition to federal courts, the Arizona, Kentucky, and Colorado supreme courts have all declared that private-private defamation cases are exempt from constitutional requirements. ${ }^{216}$ In 1986, just three months after the Supreme Court decided Hepps, the Arizona Supreme Court cited Dun \& Bradstreet and Hepps in support of its categorical conclusion that "when a plaintiff is a private figure and the speech is of private concern, the states are free to retain common law principles."217 Interestingly, as in much of the dangerous discussion of private-private standards, the statement was in dicta because the plaintiff was a public figure and the subject of the news story was a matter of public concern. $^{218}$

In a 2004 private-private case, the Kentucky Supreme Court also announced

209 Id. at *5-6 (citing Weissman v. Sri Lanka Curry House, Inc., 469 N.W.2d 471 (Minn. Ct. App. 1991)).

210 Tan v. Younis Art Studio, Inc., $2007 \mathrm{MP} 11 \mathrm{U}$, ๆ 28 n.21.

211 Id. .9 26-29.

212 Sleem v. Yale Univ., 843 F. Supp. 57, 59 (M.D.N.C. 1993).

213 Id. Yale was never able to determine who submitted the questionnaire. Id.

214 Id. at 61.

215 Id. at 61-62.

216 See Dombey v. Phoenix Newspapers, Inc., 724 P.2d 562 (Ariz. 1986); People v. Ryan, 806 P.2d 935 (Colo. 1991); Stringer v. Wal-Mart Stores, Inc., 151 S.W.3d 781, 793 (Ky. 2004).

217 Dombey, 724 P.2d at 567.

218 Id. at 556-57, 569-71. 
that constitutional protection is not triggered in suits that involve private statements made by private parties. ${ }^{219}$ In a case similar to Noonan, the Kentucky Supreme Court determined that statements related to the termination of two women for "unauthorized removal of company property" and "violation of company policy" for eating "claims candy" - candy from open or torn bags removed from the store's shelves that had been taken to the store's "claims area"-was a private matter. ${ }^{220}$ Unlike its Arizona counterpart, however, the Kentucky court failed to support its bold assertion with any citations, quotations, or discussion. ${ }^{221}$

In People v. Ryan, ${ }^{222}$ a criminal libel case, the Colorado Supreme Court referred to private-private defamation as "constitutionally unprotected conduct."223 In Ryan, which involved a man who mailed copies of a fictitious "Wanted" poster to several businesses, bars, and a local trailer park in Fort Collins, Colorado, ${ }^{224}$ the court declared that, "[I]n a purely private context, a less restrictive culpability standard may be used to meet the state's legitimate interest in controlling constitutionally unprotected conduct injurious to its citizens." 225 According to the court, the criminal libel statute in question-which

219 Stringer, 151 S.W.3d at 793.

220 Id. at $786,793$.

221 The opinion in the case contains only one citation to any United States Supreme Court decision - a mere parenthetical in which the majority actually quotes an earlier Kentucky Supreme Court opinion that quoted New York Time's definition of actual malice. Id. at 799 n.66.

${ }_{222}$ People v. Ryan, 806 P.2d 935, 935 (Colo. 1991) (en banc). Although the prevailing view of criminal libel among communication law scholars in the United States is that there are only a handful of criminal libel prosecutions per year, a recent empirical study of all Wisconsin criminal libel cases from 1991 through 2007 suggests that criminal libel might be prosecuted far more often than realized. See David Pritchard, Rethinking Criminal Libel: An Empirical Study, 14 COMM. L. POL'Y 303, 303 (2009). The deconstitutionalization of private speech is especially troublesome in criminal libel cases in light of Professor Pritchard's conclusion that criminal libel is especially likely to be used when expression harms the reputations of private figures in cases outside the scope of public issues. Therefore, if the deconstitutionalization of private speech were to continue, defendants may have no constitutional protections from criminal charges that result from speech.

223 Ryan, 806 P.2d at 939 (emphasis added). The court left it unclear why it was referring to the expression in question as "conduct," a distinction that could conceivably remove the speech from First Amendment protection regardless of the identity of the plaintiff or the subject matter of the allegedly defamatory statement.

224 The poster stated that the woman was wanted for "'fraud, conspiricy [sic] to commit fraud, various flimflam schemes, spouse abuse, child abuse-neglect, sex abuse, abuse of the elderly, prostitution, assault, larceny, theft of services, wage chiseling, [and] breach of contract." According to the court, the poster also stated the woman "'has harbored various forms of VD,' and is at 'high risk for AIDS.' In addition, the poster set forth the victim's age, hair color, weight, height, eye color, birth date, and residence, and offered a $\$ 3,000$ reward for 'information leading to the criminal or civil prosecution' of the victim." Id. at 936.

225 Id. at 939. 
did not contain an actual malice standard-was only invalid as applied to constitutionally protected statements "about public officials or public figures on matters of public concern." ${ }^{226}$ The statute, however, could be applied when a private individual has harmed the reputation of another private individual. ${ }^{227}$

In addition to those courts that have expressly declared that the privateplaintiff-private-issue defamation is unprotected by the First Amendment, many others have foregone constitutional analysis and relied on state law. These courts have failed to explicitly mention a Supreme Court decision that deals with private-private speech, ${ }^{228}$ or they have expressed uncertainty about whether constitutional limits apply. ${ }^{229}$ A 2010 Louisiana Court of Appeal decision provides a recent example of a court relying solely on state precedent ${ }^{230} \mathrm{In}$ Jalou II, Inc. v. Liner, the court relied on the "negligence standard of liability in defamation actions by private individuals involving matters of private concern" that was stated in the Louisiana Supreme Court case Costello v. Hardy. ${ }^{231}$ Interestingly, the 2004 Louisiana Supreme Court case that was cited by the court of appeals was discussing the definition of "malice" applicable in cases in which the words were not defamatory per se. ${ }^{232}$ In such cases, the state supreme court stated that the plaintiff must prove "in addition to defamatory meaning and publication, the elements of falsity, malice (or fault) and injury." 233 The court then defined malice as "a lack of reasonable belief in the truth of the statement giving rise to the defamation" and noted that it more closely resembled negligence "with respect to the truth" than spite or improper motive. ${ }^{234}$

Two examples of a court expressing uncertainty about the constitutional status of private-private defamation come from the United States Court of Ap-

226 Id. at 940.

227 Id. at 941.

228 See Walden \& Silver, supra note 128, at, 27-31 (2009), for a discussion of cases in which the courts applied common law fault requirements without explicitly stating they were doing so because the United States Supreme Court had removed the constitutional fault requirements of Gertz for private-private cases. More recent cases have continued this trend. See, e.g., Anaya v. CBS Broadcasting Inc., 626 F. Supp. 2d 1158 (D.N.M. 2009); Super Future Equities, Inc. v. Wells Fargo Bank Minnesota, N.A., 553 F. Supp. 2d 680 (N.D. Tex., 2008); Jalou II, Inc. v. Liner, 43 So. 3d 1023 (La. Ct. App. 2010). Depending on the state, these courts required different levels of fault for private-private cases. This article only discusses cases that have explicitly stated that private-private defamatory speech does not receive First Amendment protection.

229 See Walden \& Silver, supra note 128, at 21-25 (2009), for a discussion of cases in which courts voiced uncertainty or confusion regarding the impact of Dun \& Bradstreet and subsequent cases.

230 Jalou II, Inc. v. Liner, 43 So. 3d 1023 (La. Ct. App. 2010).

231 Id. at 1039 (citing Costello v. Harvey, 864 So. 2d 129, 143 (La. 2004)).

${ }^{232}$ Costello v. Hardy, 864 So. 2d 129, 140-42 (La. 2004).

233 Id. at 140.

234 Id. at 143. 
peals for the First Circuit - the same court that refused a few years later to declare Massachusetts' truth-unless-with-malice statute unconstitutional. ${ }^{235}$ In its 1997 decision, Levinsky's, Inc. v. Wal-Mart, the First Circuit stated it was "unclear whether the First Amendment prohibits a state from imposing strict liability" in private-private libel cases. ${ }^{236}$ In a 2003 decision, Andresen v. Diorio, the First Circuit deemed the issue "still formally unsettled." ${ }^{237}$ Although the First Circuit did not explicitly exclude all First Amendment protections in privateprivate libel cases in Noonan $v$. Staples, ${ }^{238}$ it seems likely that its earlier uncertainty paved the way for its willingness to permit liability for the publication of the truth.

\section{Opinion in Private-Person-Private-Issue Defamation Cases}

At least one federal court and one state appellate court have also ruled that private-private speech does not qualify as constitutionally protected opinion. ${ }^{239}$ In Roffman v. Trump, the United States District Court for the Eastern District of Pennsylvania held that only state law determines the protection available for statements of opinion in a private-private case. ${ }^{240}$ Roffman began with an article in The Wall Street Journal in which casino analyst Marvin Roffman predicted that Donald Trump's Taj Mahal in Atlantic City "won't make it. The market just isn't there." ${ }^{241}$ Trump's subsequent demands that Roffman be fired led the investment company that employed him to ultimately terminate his employment. ${ }^{242}$ Trump further responded with a barrage of attacks against Roffman in publications including the New York Post, The Philadelphia Inquirer, Barron's, Fortune, and Vanity Fair. ${ }^{243}$ Among other things, Trump called Roffman "a very unprofessional guy," "a man with little talent," and "not a good man."244 Although both parties assumed that their case would be governed by the United States Supreme Court's decision in Milkovich, ${ }^{245}$ the court asserted that "the actionability of statements of opinion in the private plaintiff/private issue context must be determined by reference to state law. $\$ 246$

In a detailed discussion of Supreme Court cases, Chief Judge Louis C.

235 See Noonan v. Staples, 561 F.3d 4 (1st Cir. 2009).

236 Levinsky's, Inc. v. Wal-Mart, 127 F.3d 122, 128 n.4 (Ist Cir. 1997).

237 Andresen v. Diorio, 349 F.3d 8, 17 n.4 (1st Cir. 2003).

238 See Noonan, 561 F.3d at 7.

239 See Roffman v. Trump, 754 F. Supp 411, 415-16 (E.D. Pa. 1990).

240 Id. at 415.

241 Id. at 413.

242 Id.

243 Id. at 413-14.

244 Id. at 413-14.

245 Milkovich v. Lorain Journal Co, 497 U.S. 1 (1990).

246 Roffman, 754 F. Supp at 415. 
Bechtle cited Dun \& Bradstreet for the proposition that while the Court had constitutionalized libel law in cases involving public figures or issues of public concerns, it had "created few restrictions" on state defamation law in cases involving private plaintiffs and private concerns. ${ }^{247}$ Two years later, the district court cited Roffman to again conclude that only state law applied to privateprivate defamation cases. ${ }^{248}$

In a good example of the potential power of minority opinions, a Minnesota Court of Appeals dissenter's opinion that "in the absence of . . a public context, a defamation action is not constitutionally significant, but rather is governed by state common law" became the holding of the court within weeks. ${ }^{249}$ In Lund v. Chicago \& Northwestern Transportation Co., Judge Gary Crippen disagreed with his two colleagues who ruled that a memo placed on a workplace bulletin board was constitutionally protected opinion. ${ }^{250}$ In his dissent, Judge Crippen relied on Dun \& Bradstreet and Hepps, while citing Roffman v. Trump, to support the following assertion: "The internal business communication at issue in this appeal is of purely private concern. The plaintiff is a private figure. Thus, we should determine the dispute according to state common law principles rather than constitutional law."2si

Just six weeks later, in Weissman v. Sri Lanka Curry House, a case involving a former employer who told a prospective employer that plaintiff was "unreliable," "dishonest," and had "walked out."252 Judge Crippen and two different colleagues boldly declared that "the Supreme Court has not extended constitutional protections for public speech to speech of purely private concern."253 After dismissing the applicability of First Amendment protection for opinion, the court declared that Minnesota common law fails to distinguish between fact and opinion, and that "[a] communication is defamatory if it causes enough

247 Id.

248 Alvord-Polk, Inc. v. F. Schumacher \& Co., Civ. A. No. 90-3617, 1992 WL 59096, at *22 (E.D. Pa. Mar. 19, 1992), aff'd in part, rev'd in part 37 F.3d 996 (3d Cir. 1994). On appeal, the Third Circuit affirmed the district court's ruling in relation to the defamation claims, applying only state law. See Alvord-Polk, Inc. v. F. Schumacher \& Co., 37 F.3d 996, 1015-16 (3d Cir. 1994).

249 Lund v. Chicago \& Nw. Trans. Co., 467 N.W.2d 366, 370 (Minn. Ct. App. 1991) (Crippen, J., dissenting).

250 Id. at $369 \mathrm{n} .1,370$ (majority opinion). The bulletin board in question read, "FAVORITISM, DICK LUND, SICK, MOVE-UPS, BROWN NOSE, SHIT HEADS.” Id. at 368.

251 Id. at 371 (Crippen, J., dissenting) (citations omitted).

252 Weissman v. Sri Lanka Curry House, Inc., 469 N.W.2d 471, 471 (Minn. Ct. App. 1991).

253 Id. at 473. In the excluded portion of the quotation, the majority also interpreted Milkovich v. Lorain Journal Co., 497 U.S. 1 (1991), as "reject[ing] a separate constitutional privilege for opinion," but that was the only portion of the majority opinion with which Judge Crippen disagreed. Weissman, 469 N.W.2d at 473 (Crippen, J., concurring specially) (citations omitted). 
harm to a person's reputation to lower the community's estimation of the individual or to deter others from associating or dealing with the individual." ${ }^{254}$ The Minnesota Court of Appeals reiterated this holding in cases that dealt with opinion in $2000^{255}$ and 2003. ${ }^{256}$ Further, as mentioned above, the Minnesota federal district court relied on Weissman to hold, in 2002, that constitutional fault requirements did not apply in private-private cases. ${ }^{257}$

Other courts have stated that it is questionable whether First Amendment protection for opinion applies to private-private cases without directly deciding the question, largely because they focused on state laws that would grant similar protections for opinion. For example, in 2011, in an unreported slander case, the New York Supreme Court expressed its uncertainty over whether constitutional protection for opinion/rhetorical hyperbole applied to privateprivate nonmedia speech. ${ }^{258}$ The court stated,

As far as this Court is aware, neither the U.S. Supreme Court nor our Court of Appeals has expressly resolved whether some or all of the identified constitutional limits apply to an action, like this one, by a private person against a "nonmedia" defendant that is not based upon a statement on a matter of public concern. ${ }^{259}$

The court further suggested the New York Constitution, not the United States Constitution, protects this type of speech. ${ }^{260}$

Similarly, in a 2008 case involving a public figure and a matter of public concern, the Illinois Court of Appeals stated in dicta that it was "unsettled" whether a constitutional privilege for opinion extended to statements made by a "private party about another on a matter of purely private concern."261 After a discussion of Supreme Court libel precedents from New York Times through Hepps, the Maryland Court of Special Appeals also expressed uncertainty, asserting that "many of the protections afforded defendants in regard to speech concerning matters of public concern and public figures or public officials may not be applicable unless afforded by Maryland law."262 The court then undertook an extensive comparison of constitutional protection for opinion and the

\footnotetext{
254 Weissman, 469 N.W.2d at 473 (majority opinion) (citations omitted).

255 Harmon v. Heartland Food Co., 614 N.W.2d 236, 241 (Minn. Ct. App. 2000) (citations omitted).

256 Dedefo v. Wake, No. C2-02-1692, 2003 WL 21219830, at *4 (Minn. Ct. App. May 27, 2003) (citations omitted).

257 Kirckof v. Brown, No. Civ. 01-476, 2002 WL 31718394, at *5 (D. Minn. Nov. 27, 2002).

258 See Kaplan v. Khan, No. 43099/07, 2011 WL 1879039, at, ${ }^{* 5-7}$ (N.Y. Sup. Ct. May 17, 2011) (citation omitted).

259 Id. at *5.

$260 I d$. at *6 (noting that the New York Court of Appeals' analysis of such cases was based on the New York Constitution).

261 Green v. Rogers, 895 N.E.2d 647, 660 (Ill. App. Ct. 2008).

262 Peroutka v. Streng, 695 A.2d 1287, 1292 (Md. Ct. Spec. App. 1997) (emphasis added).
} 
common law fair comment defense, concluding the two were essentially the same. ${ }^{263}$ The court ultimately declared that the statement in question was not defamatory because it was pure opinion, as defined by the Restatement (Second) of Torts. ${ }^{264}$

\section{The Nature of the Defendant: Media Versus Nonmedia}

In late 2011, the question of whether nonmedia libel defendants enjoy constitutional protection drew renewed attention-especially in the online worldafter the United States District Court for the District of Oregon held that a blogger did not qualify as a media defendant and, therefore, was not entitled to the protections of Gertz, ${ }^{265}$ Judge Marco Hernandez's ruling led to a jury verdict of $\$ 2.5$ million against blogger Crystal Cox, who a jury found libeled $\mathrm{Ob}$ sidian Finance Group and its co-founder, Kevin Padrick, in one of her posts. ${ }^{266}$ Cox, representing herself, sought both constitutional and statutory protections available to media and journalists, all of which Hernandez denied, declaring that "defendant is not media." 267 In this diversity action, the federal court applied Oregon law, and, in 1977, the Oregon Supreme Court had become the second state high court ${ }^{268}$ to rule that the constitutional protections enunciated in Gertz did not apply to nonmedia defendants. ${ }^{269}$

In the 1977 Oregon Supreme Court case, Harley-Davidson Motorsports, Inc. $v$. Markley, an employee of a dealership wrote a false letter of complaint about a competing motorcycle dealership. ${ }^{270}$ The court described the dispute as one lacking a public official or public figure plaintiff, a public issue, and a media defendant. ${ }^{271}$ Further, the court concluded that there was no interest in "democratic dialogue."272 The state high court relied on Gertz's references to publishers, broadcasters, and media, as well as a 1975 Wisconsin Supreme Court case, Calero v. Del Chemical Corp. ${ }^{273}$ to support its decision that the First

\footnotetext{
263 Id. at 1300.

264 Id. at 1300.

265 Obsidian Fin. Grp. LLC v. Cox, No. CV-11-57-HZ, 2011 WL 5999334, *5 (D. Or. Nov. 30, 2011).

266 Douglas Lee, Troubling Rulings Paved Way for Blogger's Libel Conviction, FIRST AMENDMENT CENTER (Dec. 19, 2011), http://commcns.org/W3vVfo.

267 Cox, 2011 WL 5999334, *5.

268 The Wisconsin Supreme Court was the first. See Calero v. Del Chem. Corp., 228 N.W.2d 737, 747 (Wis. 1975) (citation omitted).

269 Harley-Davidson Motorsports, Inc. v. Markley, 568 P.2d 1359, 1362-65 (Or. 1977).

270 Id. at 1361.

271 Id. at 1362.

272 Id. at 1364.

273 Calero, 228 N.W.2d 737.
} 
Amendment was inapplicable. ${ }^{274}$ Consequently, the court upheld a jury verdict of $\$ 500$ in general damages and $\$ 25,000$ in punitive damages without proof of fault or actual injury. ${ }^{275}$

The Wisconsin case cited by the Oregon Supreme Court to support its ruling resulted from statements made by a former employer about an accountant to prospective employers. ${ }^{276}$ Ruling less than a year after the United States Supreme Court handed down its decision in Gertz, the Wisconsin Supreme Court stated, 'Neither [New York] Times' nor Gertz' [sic] protections apply to the case before us." ${ }^{.27}$ As the Oregon court did two years later, the Wisconsin high court based its decision on the fact that "[i]n the case before us there is no matter of general or public interest; there is no public official or public figure; there is no involvement of the media, either broadcast or print." 278

The key constitutional question in Calero was whether proof of actual malice, as opposed to common-law malice, was required to sustain an award of punitive damages in matters of private concern. ${ }^{279}$ In Denny v. Mertz, however, a Wisconsin court relied on the Calero decision to strip a nonmedia libel defendant of all constitutional protections even though the case appeared to involve a matter of public interest. ${ }^{280}$ This case resulted from an effort by dissident stockholders, including William Denny, a former Koehring Corp. employee, to change the management of Koehring, of which Orville Mertz was chairman and $\mathrm{CEO}{ }^{281}$ The shareholder dispute was widely reported in Milwaukee newspapers as well as in The Wall Street Journal." ${ }^{282}$ An article in Business Week magazine, published after Mertz resigned as chairman and CEO, ultimately resulted in the libel suit. ${ }^{283}$ The magazine article erroneously stated Mertz fired Denny, who, in fact, had quit in order to enter private law practice. ${ }^{284}$ Denny sued both Mertz and Business Week. ${ }^{285}$

After finding that Denny was not a public figure, the court held that "a negligence standard [applies] in defamation actions by private individuals against the news media,"286 and actual malice would be required for Denny to be

274 Markley, 568 P.2d at 1363-65.

275 Id. at 1363-65.

276 Calero, 228 N.W.2d at 740.

277 Id. at 747.

278 Id. at 748 .

279 Id. at 748.

280 Denny v. Mertz, 318 N.W.2d 141, 153 (Wis. 1982), cert. denied, 559 U.S. 883 (1982).

281 Id. at 143.

282 Id.

283 Id. at $143-44$.

284 Id. at 143.

285 Id. at 144.

286 Id. at 151. 
awarded punitive or presumed damages from Business Week. ${ }^{287}$ The court then addressed the next question: "Does the defendant Mertz enjoy the same constitutional protection as the media publisher. [sic]" ${ }^{\prime 288}$ No, was the court's answer.

While we recognize that some courts in other jurisdictions have held that the Gertz protections apply to all defamations, regardless of whether published through the media or by private persons, we do not read Gertz as requiring that the protections provided therein apply to non-media defendants nor, as stated above, do we consider it good public policy to so decide. We reaffirm our holding in Calero that purely private defamations are not entitled to constitutional protection .... ${ }^{289}$

In separate opinions, Justices Shirley Abrahamson and Nathan Heffernan asserted that they believed that media and nonmedia libel defendants were entitled to the same constitutional protections. ${ }^{290}$

Although the Wisconsin Supreme Court never explicitly restricted its noconstitutional-protection-for-nonmedia-defendants holding to cases in which plaintiffs were private persons, ${ }^{291}$ the United States Court of Appeals for the Seventh Circuit put that spin on Denny v. Mertz twelve years later. ${ }^{292}$ Controversial psychologists Ralph Underwager and Hollida Wakefield, who wrote two books contending that "most accusations of child sexual abuse stem from memories implanted by faulty clinical techniques," sued another psychologist and a former prosecutor, who was the director of the National Center for Prosecution of Child Abuse, after they publicly challenged Underwager's and Wakefield's conclusions. ${ }^{293}$ Plaintiffs, whom the court held were limited purpose public figures in discussions regarding child abuse, argued that they were not required to prove actual malice under Wisconsin law because neither defendant was a media defendant. ${ }^{294}$ Acknowledging that " $[t]$ here is still doubt whether the Constitution applies the same standards to media and private de-

287 Id. at 152. It is important to recognize that Denny was decided before the Supreme Court created the "matter of public concern" standard for punitive and presumed damages in Dun \& Bradstreet, Inc. v. Greenmoss Builders, Inc., 472 U.S. 749, 751 (1985). While the court recognized the Koehring stockholder dispute was "newsworthy," it did not address whether the issue constituted a matter of public concern, but simply held that it was not a "public controversy" for determining limited public figure status because it "did not have an impact outside of those immediately interested in the Koehring corporation." Mertz,_318 N.W.2d at 148 .

288 Mertz, 318 N.W.2d at 152.

289 Id. at 153 (citations and footnote omitted).

290 Id. at 155 (Heffernan, J., concurring); id. at 155 (Abrahamson, J., dissenting).

291 In 1995 and again in 2011 the Wisconsin Court of Appeals avoided ruling on whether the actual malice requirement applied in libel suits brought by public figure plaintiffs against nonmedia defendants. Krans v. Wicklund, No. 2010AP489, 2011 WL 321820, at *2 n.4 (Wis. Ct. App. Feb. 3, 2011 ); Bay View Packing Co. v. Taff, 543 N.W.2d 522, 529 n.5 (Wis. Ct. App. 1995).

292 Underwager v. Salter, 22 F.3d 730, 734 (7th Cir. 1994).

293 Id. at 731-32.

294 Id. at 734. 
fendants," the Seventh Circuit stated the question was not how the United States Supreme Court would rule, but rather how the Wisconsin court interprets its state law. ${ }^{295}$ The court went on to assert:

None of the cases we could find suggests that Wisconsin imposes a lesser burden on a public figure suing a psychologist or prosecutor than on one suing a reporter. Actually, we could not find cases either way on this subject; all of Wisconsin's "public figure" cases were against media defendants. ${ }^{296}$

However, after emphasizing it was just addressing Wisconsin law, the Seventh Circuit cited reasons not to treat media and nonmedia defendants differently, which clearly apply nationwide:

Just as the public has a strong interest in providing reporters with a qualified privilege to report on current events without fear of liability for accidental misstatements, so the public has a strong interest in protecting scholars and prosecutors. . . [T] he private need for the privilege may well be greater in the case of scholars and prosecutors than in the case of newspapers and broadcasters. Newspapers, magazines, and broadcast stations reap considerable profits from their endeavors, and ... [damages are] unlikely to put them out of business or even substantially temper their reports. . . Psychologists ... and prosecutors ... do not receive comparable rewards. Exposing such persons to large awards of damages is more apt to lead to silence than are comparable awards against media defendants. ${ }^{297}$

In a slander per se case, the Colorado Supreme Court reversed a state appeals court ruling, ${ }^{298}$ making it the third state high court to rule that Gertz did not apply to a private plaintiff defamed by a nonmedia defendant in a "purely private context." ${ }^{\text {"299 }}$ The Vermont Supreme Court cited the Colorado, Wisconsin, and Oregon decisions approvingly when it ruled in Greenmoss Builders $v$. Dun \& Bradstreet that Gertz's constitutional protections were inapplicable in libel cases involving private plaintiffs and nonmedia defendants. ${ }^{300}$ After the United State Supreme Court's decision in Dun \& Bradstreet, the Vermont high court questioned the continued viability of its media-nonmedia distinction but did not explicitly abrogate that ruling. ${ }^{301}$

295 Id. at 734.

296 Id.

297 Id. at 734-735.

298 Rowe v. Metz, 564 P.2d 425, 428 (Colo. App. 1977) ("[W]e hold that Gertz applies in non-media defamation actions and that thus the imposition of liability without fault is impermissible in such cases."), rev'd, 579 P.2d 83 (1978).

299 Rowe v. Metz, 579 P.2d 83, 84-85 (Colo. 1978) (noting that neither the appeals court nor the supreme court reported the nature or content of the defamatory statements).

300 Greenmoss Builders, Inc. v. Dun \& Bradstreet, Inc., 461 A.2d 414, 418 (Vt. 1983), aff'd on other grounds, 472 U.S. 749 (1985).

301 Ryan v. Herald Ass'n, Inc., 566 A.2d 1316, 1319 n.1 (Vt. 1989) ("The United States Supreme Court's rejection of this Court's rationale in Dun \& Bradstreet, however, casts doubt on the vitality of the distinction for constitutional purposes."). The court ultimately concluded that, because the case at hand involved a newspaper defendant, "Gertz is unequivocally controlling." Id. 


\section{REASONS TO AVOID THE DANGEROUS DISTINCTION}

During the past twenty-five years, lower courts have begun the process of deconstitutionalizing private-figure-private-issue defamation as part of a broader trend of the Supreme Court granting greater protection to political speech in cases involving government employee speech, ${ }^{302}$ intentional infliction of emotional distress, ${ }^{303}$ false light invasion of privacy, ${ }^{304}$ and other areas of law. ${ }^{305}$ Currently, the First Circuit's opinion in Noonan v. Staples is the only circuit court opinion in which a court has refused to declare that the First Amendment prohibits liability for true defamatory private-private speech. ${ }^{306}$ Nonetheless, the prospect of similar rulings exists, with some nineteen states having constitutional or statutory provisions that allow criminal or civil liability for truth unless it is published with "good motives." ${ }^{307}$ At least six state and federal courts, including the United States Court of Appeals for the Fifth Circuit, have held that the Constitution does not require fault in private-private cases. $^{308}$ At least two courts have explicitly ruled that there is no constitutional protection for opinion in such cases. ${ }^{309}$ Meanwhile, many more courts have voiced uncertainty and confusion over whether constitutional limits exist in private figure-private issue defamation cases. ${ }^{310}$

Notably, only two United States Supreme Court Justices-Byron White and Warren Burger-have ever expressly stated private-figure-private-issue defamatory speech is wholly without First Amendment protection. ${ }^{311}$ Despite this fact, scholars, federal judges, and state appellate judges have concluded that

302 See Connick v. Myers, 461 U.S. 138, 154 (1983) (recognizing the "practical realities" in regards to the actions of employees in government offices); Pickering v. Bd. of Educ., 391 U.S. 563, 573 (1968) (denying recovery for defamatory statements unless made with knowledge of falsity).

303 See, e.g., Snyder v. Phelps, 131 S. Ct. 1207, 1215 (2011) ("The Free Speech Clause of the First Amendment . . . can serve as a defense in state tort suits, including suits for intentional infliction of emotional distress.").

304 See, e.g., Time, Inc. v. Hill, 385 U.S. 374, 387-88 (1967) (First Amendment protections require a showing that defendant acted with knowledge of report's falsehood or acted with reckless disregard of the truth).

305 See, e.g., Bartnicki v. Vopper, 532 U.S. 514, 535 (2001) (illegally recorded conversation regarding matter of public concern released by media protected by First Amendment).

306 Noonan v. Staples, 561 F.3d 4 (Ist Cir. 2009).

307 See supra notes 179-181 and accompanying text; e.g., Denny v. Mertz, 318 N.W.2d 141, 158 n.4 (Wis. 1982) (Abrahamson, J., dissenting) (quoting WIS. CoNST. art. I, $\S 3$ ).

308 See supra Part IV.B.

309 Milkovich v. Lorain Journal Co., 497 U.S. 1, 18-19 (1990); Gertz v. Robert Welch, Inc., 418 U.S. 323, 339-40 (1974).

310 See Walden \& Silver, supra note 128, at 21-25, for a discussion of cases in which courts voiced uncertainty or confusion regarding private figure-private issue defamation cases.

311 Dun \& Bradstreet, Inc. v. Greenmoss Builders, Inc., 472 U.S. 749, 763-64 (1985) (Burger, C.J., concurring). 
language used in the various opinions in Dun \& Bradstreet ${ }^{32}$ and in the majority opinion in Hepps justifies the deconstitutionalization of private speech. ${ }^{313}$ Because Dun \& Bradstreet involved both a private figure plaintiff and a matter not of public concern, the plurality's references to speech of "reduced constitutional value" 314 and "less First Amendment concern"315 were part of the ratio decidendi. ${ }^{316}$ Hepps, however, involved a matter of public concern. Consequently, Justice O'Connor's declaration that the First Amendment has "not necessarily" changed "some of the features of the common-law landscape" as it applies to private-private defamation was merely dicta. ${ }^{317}$

Of course, it is not uncommon for lower courts to use Supreme Court dicta as the basis for their decisions. Indeed, a key purpose of the Court's opinion in Milkovich ${ }^{318}$ seemed to be to put a halt to misuse of a dictum from Gertz: "Under the First Amendment there is no such thing as a false idea." ${ }^{319}$ In Milkovich, the Court stated, "[W]e do not think this passage from Gertz was intended to create a wholesale defamation exemption for anything that might be labeled "opinion.", 320

It is time now for the Supreme Court to do the same thing regarding the misuse of its Hepps dictum and Dun \& Bradstreet language regarding "reduced" and "less" constitutional protection for private speech. "We do not think these passages were intended to create a wholesale exemption from the First Amendment for anything that might be labeled 'private speech"' has become a much-needed pronouncement by the Court. ${ }^{321}$

There are compelling normative and practical reasons for continuing to recognize First Amendment limitations on defamation law as it applies to private speech. First, Meiklejohn, Bork, and other theorists notwithstanding, the First Amendment does not say, "Congress shall make no law abridging political [or public] speech." The contextual argument that coupling speech and press protection with the right to assemble and petition government indicates the framers' vision of an amendment designed to protect only the discussion of matters of public concern in order to promote self-governance begs the question of why, then, those same framers would couple such purely public interest-based

312 See generally id. at 759 (1985) (majority opinion).

313 See generally Phila. Newspapers, Inc. v. Hepps, 475 U.S. 767, 776 (1986).

314 Dun \& Bradstreet, 472 U.S. at 761 .

315 Id. at 759.

316 Ratio decidendi is defined as "The principle or rule of law on which a court's decision is founded." BLACK's Law DictionaRY 1376 (9th ed. 2009).

317 Hepps, 475 U.S. at 775.

318 Milkovich v. Lorain Journal Co., 497 U.S. 1, 18 (1990).

319 Gertz v. Robert Welch, Inc., 418 U.S. 323, 339 (1974).

320 Milkovich, 497 U.S. at 18.

321 Id. 
rights with protection for what is surely one of the most personal and individualistic decisions a person makes-whether and how to worship a deity. ${ }^{322}$

Despite BeVier's, Weinstein's, and other theorists' critiques, values other than self-governance have a long and important history in the development of First Amendment theory and doctrine. Indeed, it is hard to imagine justifying First Amendment protection for sexually explicit and obscene speech, ${ }^{323}$ nude dancing, ${ }^{324}$ violent video games, ${ }^{325}$ and commercial advertising ${ }^{326}$ without recognition of freedom of expression's role in promoting individual selffulfillment and a robust marketplace of political, social, and commercial ideas. While it is possible to construct a definition of political speech that protects a broad range of expression, as Post did in his "public discourse" concep ${ }^{327}$ and Meiklejohn did in his later writings, ${ }^{328}$ it is much easier to simply admit that the Court has indeed extended protection to speech that has little to do with selfgovernance, politics, or public debate.

The Court has embraced many First Amendment values over the years that have little to do with political speech or self-government. Normatively, it is difficult to imagine a principled way of explaining why a Staples vice president's true statement to employees that a co-worker was fired for violating the company's travel and expense policy is not protected by the First Amendment $^{329}$ but video games in which "[v]ictims are dismembered, decapitated, disemboweled, set on fire, and chopped into little pieces" are entitled to constitutional protection. ${ }^{330}$ Similarly, it makes little sense that Donald Trump's assertion that an analyst who predicted failure for his Atlantic City casino was "a

322 See U.S. CONST. amend. I (stating "Congress shall make no law respecting an establishment of religion, or prohibiting the free exercise thereof").

323 See, e.g., Miller v. California, 413 U.S. 15, 26 (1973) (stating that "prurient, patently offensive depiction[s] or description[s] of sexual conduct must have serious literary, artistic, political, or scientific value to merit First Amendment protection").

324 See, e.g., City of Erie v. Pap's A.M., 529 U.S. 277, 289 (2000) (stating that the type of nude dancing at issue in the case "falls only within the outer ambit of the First Amendment's protection").

325 See Brown v. Entm't Merchs. Ass'n., 131 S. Ct. 2729, 2733 (2011) (stating that, because "video games communicate ideas . . . and . . . social messages[,]" they are protected under the First Amendment).

326 See Va. State Bd. of Pharmacy v. Va. Citizens Consumer Council, 425 U.S. 748, 762 (1974) (stating that "speech which 'does no more than propose a commercial transaction"” does not lack First Amendment protection).

327 Post, supra note 109 , at 486.

328 MEIKLEJOHN, FREE SPEECH, supra note 1, at 26.

329 Noonan v. Staples, Inc., 556 F.3d 20, 28 (Ist Cir. 2009) (stating that the constitutionality of a Massachusetts law allowing libel cases where there is evidence of malice in truthful statements was not an issue that was initially addressed, and therefore, was not decided in this case).

330 Brown, 131 S. Ct. at 2749 (Alito, J., dissenting). 


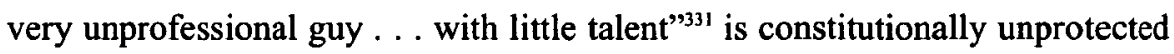
while videos that "depict women slowly crushing animals to death "with their bare feet or while wearing high heeled shoes" are protected by the First Amendment. ${ }^{332}$ Some judges seem to overlook that removing private-private defamation from the purview of the First Amendment equates such speech with obscenity, ${ }^{333}$ incitement to imminent violence that will "likely produce such action," ${ }^{334}$ and true threats. ${ }^{335}$

Furthermore, lower courts are removing protection from private speech at a time when, as the Court noted, new communication technologies are giving the average citizen "a voice that resonates farther than it could from any soapbox." 336 Removing constitutional protection for private defamatory speech threatens vast amounts of information and opinion in an Internet age. Millions of people each day check social networking sites, consumer review and evaluation sites, blogs, and tweets for both information and entertainment. ${ }^{337}$ Given courts' rulings on what constitutes speech regarding non-public issues, ${ }^{338}$ it is highly likely that much of the information posted on such websites would fall into the category of private-private speech.

Simply because the speech is about a private figure and involves what a court later decides is not of public concern, does not mean that the speech was not of importance to the speaker or the audience. Consider, for example, the speech at issue in Roffman v. Trump, where, as noted above, Donald Trump's attacks on Roffman's professional abilities and character were published in major national and regional newspapers and magazines. ${ }^{339}$ Clearly, Roffman's competence as an analyst was of significant importance to the speaker and presumably to the readers of respected business and general publications who received his message.

Roffman illustrates another major issue with denying constitutional protection to speech that a court deems is not of public interest. The concept "pubic interest" or "public concern" is undefined and, perhaps, indefinable. Reporters and editors at Fortune, the New York Post, and the other publications believed there to be sufficient public interest in the story to justify publishing Trump's

331 Roffman v. Trump, 754 F. Supp. 411, 413-14 (E.D. Pa. 1990).

332 United States v. Stevens, 130 S. Ct. 1577, 1583 (2010).

333 See Miller v. California, 413 U.S. 15 (1973).

334 See Brandenburg v. Ohio, 395 U.S. 444, 447 (1969) (per curiam).

335 See Virginia v. Black, 538 U.S. 343 (2003).

336 Reno v. ACLU, 521 U.S. 844, 870 (1997).

337 See Facebook Statistics, Stats \& Facts for 2011, Digital Buzz Blog (Jan. 18, 2011), $\mathrm{http} / / /$ commcns.org/X1LmDb (reporting that in 2011 , an average of 250 million people logged in to Facebook daily); Ben Parr, Twitter Has 100 Million Monthly Active Users; $50 \%$

Log In Every Day, MASHABLE (Oct. 17, 2011), http://commcns.org/VfwNiy.

338 See supra notes 193-263 and accompanying text.

339 Roffman v. Trump, 754 F. Supp. 411, 413-14 (E.D. Pa. 1990). 
remarks. Nonetheless, the court decided to second-guess those news judgments, holding that "the statements that form the basis of Roffman's defamation action relate to Roffman's competence and integrity ... [which] are of no concern to the general public." $" 340$

Recall Justice Powell's statement in Gertz regarding the "difficulty of forcing state and federal judges to decide on an ad hoc basis which publications address issues of 'general or public interest' and which do not." ${ }^{\text {"31 }}$ Justice Powell continued, "We doubt the wisdom of committing this task to the conscience of judges. ${ }^{.342}$ In the decades following Gertz, numerous scholars have documented the difficulty of that task. ${ }^{343}$ As Professor Nate Stern concluded in 2000:

The struggle by lower courts to interpret the Court's terse pronouncements on the distinction between public and private concerns has not crystallized into a useful methodology. Rather, courts have generally proceeded by way of ad hoc analyses or ipse dixit conclusions. The inability of courts to translate this doctrine into a lucid framework ... does not represent a failure of judicial imagination. Instead ... the enterprise was destined to founder because of the inherent indeterminacy of the distinction between public and private concerns in defamatory expression. ${ }^{344}$

Surely, if this was true in 2000 , before the advent of Facebook, ${ }^{345}$ Twitter, $^{346}$ and other means of communication over the Internet, the task has become only more complex with the introduction and widespread adoption of these technologies by both the press and the public.

A similar definitional problem exists for scholars such as Post and Meiklejohn, who took great pains to conceptualize public or political speech broadly. Post, for instance, attempted to create a context-focused, contentneutral definition of political speech, which allowed him to extend protection to abstract art as long as the art contributed to the "public discourse." 347 Post, however, admitted decisions are frequently content-based when he turned to the specifics of defamation. ${ }^{348}$ Although Post provided an example of how

\footnotetext{
340 Id. at 418.

${ }^{341}$ Gertz v. Robert Welch, Inc., 418 U.S. 323, 346 (1974).

342 Id. at 346.

343 See Stern, supra note 122, at 613-35 (discussing the failure of lower courts to clearly articulate whether speech addresses a matter of public concern); see also Drechsel, supra note 121; Langvardt, supra note 123; Smith, supra note 120.

344 Stern, supra note 122, at 598.

${ }^{345}$ Facebook launched in 2004. Sid Yadav, Facebook-The Complete Biography, MASHABLE (Aug. 25, 2006), http://commcns.org/106uhPJ.

${ }_{346}$ Twitter was founded in 2006. Eric Savitz, Jack Dorsey: Leadership Secrets of Twitter and Square, FORBES (Oct. 17, 2012), http://commens.org/106ux0T.

347 Post, supra note 109, at 486 ("Public discourse includes all communicative processes deemed necessary for the formation of public opinion. Art and other forms of nocognitive [sic], nonpolitical speech fit comfortably within the scope of public discourse.").

${ }^{348} I d$. at 480 . When discussing defamation, Post admits that under current Fist Amendment doctrine constitutional protections turns on whether the expression is about a private
} 
defamation law could be content-neutral, ${ }^{349}$ he also expressed a willingness to focus on the content of speech when denying protection to private-concernprivate-plaintiff defamatory speech. ${ }^{350}$

If Post were interested in protecting the public sphere, it would seem that expression available in newspapers and on the Internet should be protected regardless of its content or context. Have not newspapers long been considered institutions of the public sphere? Under this content-neutral analysis, as Professor C. Edwin Baker concludes, "Should not all newspaper content be as protected as it is when describing public officials' performance of public duties?"351 It would also seem that Post should be willing to protect much of what is expressed on the Internet, given the "utopian rhetoric"352 about the ability of new media technologies to further democratize post-industrial society and create a new Habermasian public sphere. Further supportive of this notion is the ongoing efforts to keep the Internet free from burdensome overregulation by public and private entities in order to maintain its democratic nature. ${ }^{353}$ While efforts to keep the Internet "free" structurally through net neutrality are extremely important, one wonders whether the Internet can deliver on its promise to democratize the public sphere if much of the expression on blogs, Facebook, and Twitter could be deemed private speech unprotected by the First Amendment.

Other problems arise when courts consider audience size in determining whether speech is on a matter of public or private concern. Although the Dun \& Bradstreet plurality opinion stated that it was " content, form, and context" that determine whether speech involves a public matter ${ }^{354}$-a formulation taken

individual and private concern or about a public person and a public concern.

$349 \mathrm{Id}$. at 481 . As an example of his approach, Post discusses how context would affect speech in a content-neutral way by differentiating between a dentist giving medical advice in the mass media and a dentist giving identical medical advice to his patient.

$350 \mathrm{Id}$. at $\mathbf{4 8 0}$ (discussing different constitutional protections for speech about a private person and a private concern and speech about a public official).

351 Baker, supra note 25, at 517.

352 Zizi Papacharissi, The Virtual Sphere: The Internet as a Public Sphere, 4 NEW MEDIA and Society 9, 9 (2002); see generally, Zizi Papacharissi, A Private SPHere: DemocRACY IN A DIGITAL AGE (2010) (discussing the democratizing potential of digital media and the Internet's relationship to Habermas' conceptualization of the public sphere).

353 See generally LaWrence Lessig, Code version 2.0 (2006); Dawn C. Nunziato, Virtual Freedom: Net Neutrality and Free SpeEch in the INTERnet Age (2009): Siva Vaidhyanathan, The GoOglization of Everything: AND Why We Should WorRy (2011); BARBARA VAN SCHEWICK, INTERNET ARCHITECTURE AND INNOVATION (2010); JONATHAN ZitTRAIN, THE FUTURE OF THE INTERNET AND HOW TO STOP IT (2008); Jack M. Balkin, Media Access: A Question of Design, 76 Geo. Wash. L. Rev. 933 (2008); Timothy Wu, Network Neutrality, Broadband Discrimination, 2 J. on Telecomm. \& High Tech. L. 141 (2003).

354 Dun \& Bradstreet, Inc. v. Greenmoss Builders, Inc., 472 U.S. 749, 762 n.8 (1985). 
from Connick v. Myers ${ }^{355}$ - the opinion also suggested that the size of the intended audience factored into its consideration, ${ }^{356}$ something that later opinions have mentioned as well. In Snyder v. Phelps, for example, after admitting that the Court itself had recently suggested that "the boundaries of the public concern test are not well defined," Chief Justice John Roberts nonetheless set out to articulate "some guiding principles" of the test. ${ }^{357}$ Roberts began by noting that speech on a matter of public concern can " "be fairly considered as relating to any matter of political, social, or other concern to the community' or when it 'is a subject of legitimate news interest; that is, a subject of general interest and of value and concern to the public." 338 Private speech, on the other hand, "concerns no public issue."" 359 Roberts said one factor that "confirmed" the credit report at issue in Dun \& Bradstreet was private speech was that it "was sent to only five subscribers." issue in Snyder, which was "designed, unlike the private speech in Dun \& Bradstreet, to reach as broad a public audience as possible." ${ }^{\prime 31}$

Adding audience size to the public interest calculus is especially problematic in today's Internet environment as it requires courts to take into account how large an audience or how many "followers" a speaker may have in a forum like Facebook or Twitter. Would, for instance, a tweet by Lady Gaga, who currently has more than 30 million followers, ${ }^{362}$ be treated differently than a Twitter user with 600 followers? ${ }^{363}$ Would a blog post by an unknown writer be treated differently than a blog post on the widely read Volokh Conspiracy, ${ }^{364}$ even if the topic of both posts was similar? If, as Post suggests, we should approach defamation in a content-neutral way, the response would be yes. Identical content in different contexts would lose constitutional protection. ${ }^{365}$ What

355 Connick v. Myers, 461 U.S. 138, 147 (1983). Unfortunately, both Connick and Dun \& Bradstreet were less than clear about how this formulation should be used, something the Court later admitted itself.

356 See Dun \& Bradstreet, 472 U.S. at 762 ("[P]etitioner's credit report concerns no public issue. It was speech solely in the individual interest of the speaker and its specific business audience.") (emphasis added). But see id. at 782 n.6 (1985) (Brennan, J., dissenting) ("Nor is there any reason to treat petitioner differently than a more widely circulated publication because it has 'a limited number of subscribers."').

357 Snyder v. Phelps, 131 S. Ct. 1207, 1216 (2011) (quoting San Diego v. Roe, 543 U.S. $77,83(2004))$.

358 Id. (quoting Connick v. Myers, 461 U.S. 138, 146 (1983) and San Diego v. Roe, 543 U.S. 77, 83-83 (2004)).

359 Id. (quoting Dun \& Bradstreet v. Greenmoss Builders, 472 U.S. 749, 762 (1985).

360 Id.

361 Id. at 1217.

362 See http://commcns.org/XAWwRZ (last visited Nov. 10, 2012).

363 See, e.g., http://commcns.org/Y7o9q2 (last visited Nov. 10, 2012).

364 See VOLOKH CONSPIRACY, http://commcns.org/W5i2fL (last visited Nov. 10, 2012).

365 Post, supra note 109, at 481 (arguing that different constitutional protections should exist for a dentist giving medical advice to an individual patient and a dentist giving medical 
does this say of the email in question in Noonan $v$. Staples that was sent to approximately 1500 Staples employees? ${ }^{366}$ Surely that is a fairly large "intended audience." And what of expression that goes viral? In the age of the Internet, even the most private video, picture, or Facebook post can quickly go viral and have an audience of thousands, if not millions. Courts are already having difficulty applying the public concern test without having to ascertain whether an Internet speaker "intended" her message to reach a large audience. ${ }^{367}$

Finally, Denny v. Mertz illustrates the illogic of considering the media or nonmedia nature of a speaker in determining the availability of constitutional protection for speech. ${ }^{368}$ As noted above, the case began when William A. Denny, a dissident stockholder and former employee of Koehring Co., a publicly held corporation, sought to oust CEO Orville R. Mertz. ${ }^{369}$ When Mertz resigned, Business Week, deciding the story "would interest the general 'business community"' published a story on Mertz's resignation. ${ }^{370}$ The article stated, "Also about that time, William Denny, general counsel of Koehring until Mertz fired him in 1969, began to question many of Koehring's management decision." 371 Denny, who had resigned from the company, sued both Mertz and McGraw-Hill, Inc., publisher of Business Week, for defamation. ${ }^{372}$ Based on the Supreme Court's pre-Dun \& Bradstreet opinions, the Wisconsin Supreme Court allowed Business Week to claim First Amendment protections, ${ }^{373}$ but not Mertz, the source of the story ${ }^{374}$ Of course, it is quite possible that the same result would have been reached if both defendants had received constitutional protection. Business Week might not have been negligent in quoting the former CEO of a company about the circumstances under which the general counsel left and Mertz might well have been negligent in his false statement. ${ }^{375}$ However, deeming one defendant to be at fault and the other not is a far cry from stating that one defendant is not entitled to any constitutional protection while the other is shielded from liability by the First Amendment.

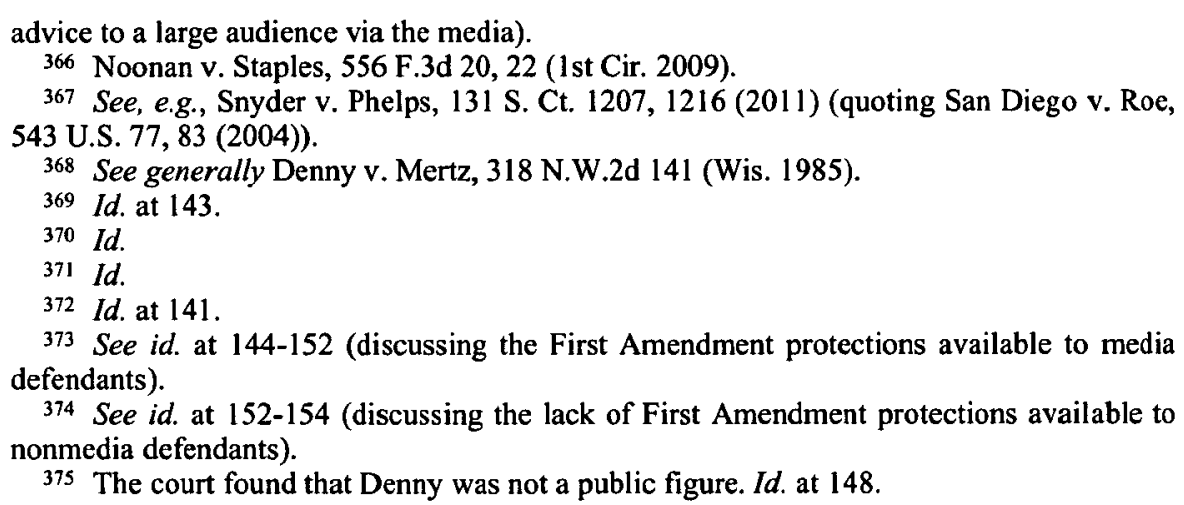




\section{CONCLUSION}

It is clear the Court's defamation jurisprudence has generated uncertainly in the lower courts. ${ }^{376}$ As current Supreme Court Justice Elena Kagan once wrote, libel law is "subject to a bewildering variety of constitutional standards." do not dispute that the primary purpose of the First Amendment is to protect political or public speech. This does not mean, however, that speech on matters deemed nonpolitical or nonpublic was intended to be or should be wholly unprotected by the Amendment, particularly in an age in which Internet communications are rapidly changing our ability to communicate with each other. The solution to the uncertainty created by the Court's statements regarding constitutional protection for speech on matters of private concern is really quite simple.

First, the Court should remove the limitation it created in Hepps and require all plaintiffs, regardless of the subject matter of the report, to prove the falsity of the defamatory statements. Falsity is an element of the offense of defamation, and, as with other tort claims, the plaintiff should be required to prove all elements of the offense he or she is alleging. The natural and inevitable corollary of proof of falsity being required for all defamation plaintiffs is that the constitutional opinion defense also applies to all defamation cases, regardless of plaintiff's status or subject matter. Opinion, by definition, is unverifiable; hence, pure opinion should never be actionable.

Next, the Court should clearly state that the nature of the defendant-media or nonmedia-is irrelevant to the availability of constitutional protection in defamation cases. First Amendment protections are just as available to the individual speaker as to the global media corporation. ${ }^{378}$ Finally, the Court should return to the fault rules it established in Gertz: public plaintiffs must prove actual malice and private plaintiffs, regardless of subject matter, must prove negligence to collect compensatory damages, and all plaintiffs, regardless of subject matter, must prove actual malice for punitive or presumed damages. Obviously this last step requires the Court to repudiate its Dun \& Bradstreet holding, an unlikely occurrence. At a minimum, therefore, the Court must make it clear that at least negligence is required in all private figure cases for any dam-

376 See, e.g., supra notes $227-263$ and accompanying text.

377 Elena Kagan, Private Speech, Public Purpose: The Role of Governmental Motive in First Amendment Doctrine, 63 U. CHI. L. REV. 413, 473 (1996).

378 See Branzburg v. Hayes, 408 U.S. 665, 704 (1972) ("[L]iberty of the press is the right of the lonely pamphleteer who uses carbon paper or a mimeograph just as much as of the large metropolitan publisher who utilizes the latest photocomposition methods."); Lovell v. Griffin, 303 U.S. 444, 450, 452 (1938) (contending that freedom of the press "is not confined to newspapers and periodicals. It necessarily embraces pamphlets and leaflets" and "comprehends every sort of publication which affords a vehicle of information and opinion."). 
ages. Admittedly, a plaintiff's status as a public or private figure is not always clearly delineated. Nonetheless, courts now have more than forty years of experience and precedents in addressing that issue, and a level of predictability and consistency has been attained. The same cannot be said of "matter of public concern." That is too slippery of a concept to serve as the basis for determining when First Amendment rights apply. 